
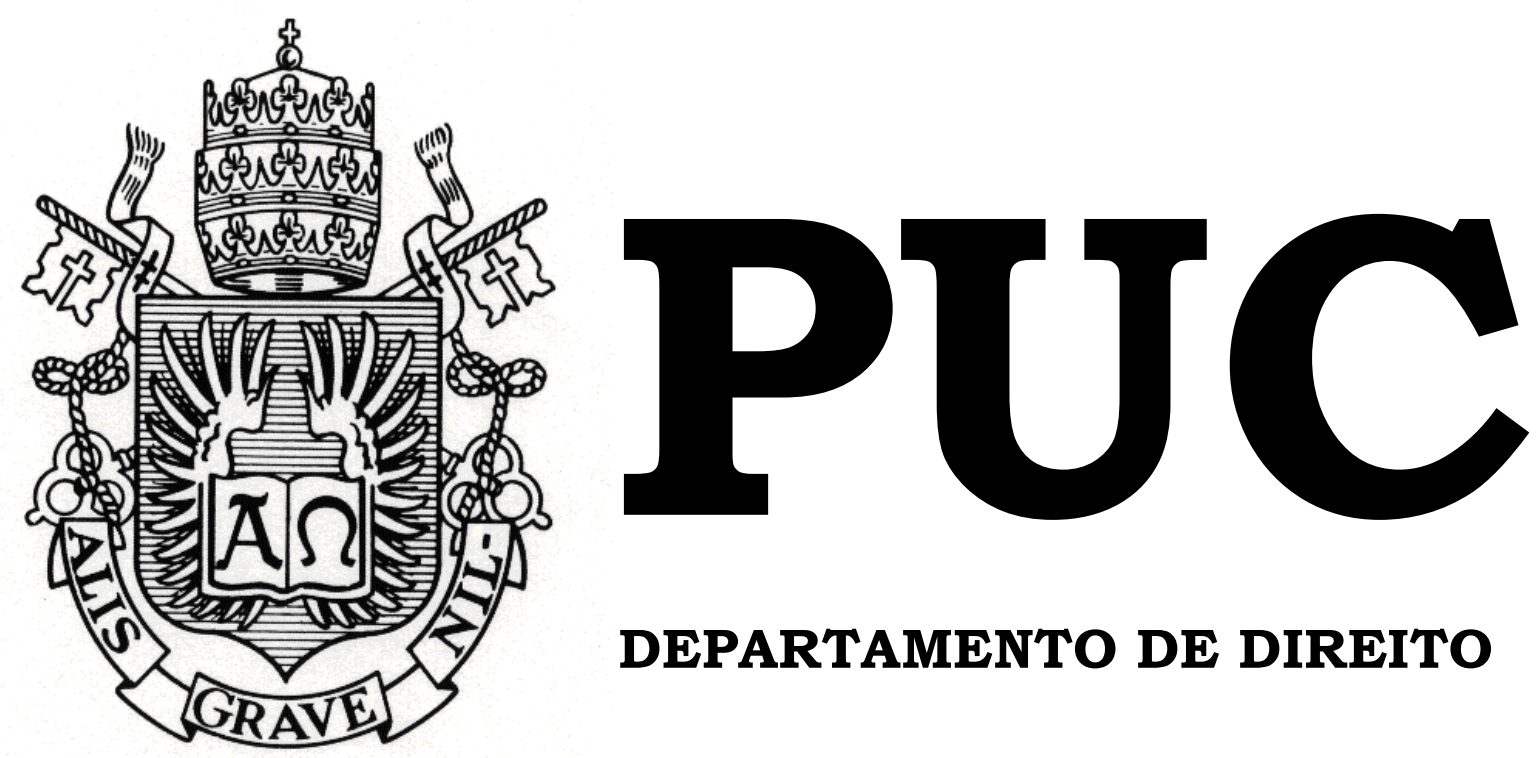

DEPARTAMENTO DE DIREITO

\title{
A PROTEÇÃO PENAL À DIGNIDADE SEXUAL DA CRIANÇA E DO ADOLESCENTE Por
} RENATA WANDERLEY ORTENBLAD

ORIENTADOR: Carlos Raymundo Cardoso 2018.1

PONTIFÍCIA UNIVERSIDADE CATÓLICA DO RIO DE JANEIRO RUA MARQUÊS DE SÃO VICENTE, 225 - CEP 22451-900 RIO DE JANEIRO - BRASIL 


\section{A PROTEÇÃo PENAL À DIGNIDADE SEXUAL DA CRIANÇA E DO ADOLESCENTE}

por

RENATA WANDERLEY ORTENBLAD

Monografia apresentada ao

Departamento de Direito da

Pontifícia Universidade Católica do

Rio de Janeiro (PUC-Rio) para a obtenção do Título de Bacharel em Direito.

Orientador: Carlos Raymundo Cardoso

2018.1 


\section{AGRADECIMENTOS}

Primeiramente, gostaria de agradecer ao meu orientador, Professor Carlos Raymundo, cuja erudição foi elementar para a elaboração desta monografia.

Como não poderia deixar de ser, dedico este trabalho à minha mãe, Andrea, inspiração para todos os meus passos e dona de um compasso moral que sempre me serviu como norte.

Também cabe agradecer ao meu pai, Carlos Arthur, fonte de estímulo intelectual e quem me proporcionou todas as oportunidades que estavam ao seu alcance.

Por fim, impossível não mencionar os meus avós, Cleide e Maurício, donos dos maiores corações do mundo, por quem sinto carinho e admiração.inesgotáveis. 


\section{RESUMO}

ORTENBLAD, Renata Wanderley. A Proteção Penal à Dignidade Sexual da Criança e do Adolescente. Rio de Janeiro: 2018: 96 p. Monografia de final de curso. Departamento de Direito da Pontifícia Universidade Católica do Rio de Janeiro - PUC-Rio.

Muito mais do que uma mera legislação, o Estatuto da Criança e do Adolescente representou um marco inaugural, na ordem infraconstitucional, da nova ótica do Estado para com a infanto-juventude, segmento que ganhou visibilidade a partir da Constituição Cidadã de 1988. A novel Carta Magna representou verdadeira troca de paradigma no tratamento dispensando a essa parcela da população, que passou a ser abarcada pela Doutrina da Proteção Integral, filosofia que os compreende como sujeitos de direitos em momento peculiar de desenvolvimento biopsicossocial, a demandar, portanto, abordagem diferenciada. Após a promulgação do ECA, novas medidas legislativas foram adotadas para fomentar as previsões constitucionais dispostas no famigerado art. 227, valendo ressaltar a Reforma de 2009 do Código Penal, que almejou, dentre outras coisas, compatibilizar a legislação criminal à nova gama de direitos atribuída aos menores de idade, o que foi realizado por meio da introdução de tipos penais inéditos. Nessa esteira é que vêm à tona os delitos contra a dignidade sexual de vulneráveis, consubstanciados no Título VI, Capítulo II, do CP, assim como no Título VII, Capítulo I, Seção II, do ECA. Nesse diapasão, o presente trabalho tem por objetivo analisar as normas jurídicas afetas ao tema, bem como examinar os agentes ativos de tais delitos, almejando, assim, não só provocar reflexões quanto a possíveis preconceitos em relação à pedofilia como também contemplar soluções estratégicas de combate ao abuso sexual de crianças e adolescentes. 
Palavras-Chave: Código Penal; Estatuto da Criança e do Adolescente; Doutrina da Proteção Integral; Crimes contra a dignidade sexual de vulnerável; Pedofilia. 


\section{SUMÁRIO}

INTRODUÇÃO ..................................................................................................... 8

CAPÍTULO 1 - PANORAMA DA PROTEÇÃO JURÍDICA CONFERIDA À CRIANÇA E AO ADOLESCENTE ............................. 10

1.1 Breve histórico do tratamento do "menor" no Brasil ......................... 10

1.2 Mudança de paradigma promovida a partir da Constituição de 1988:

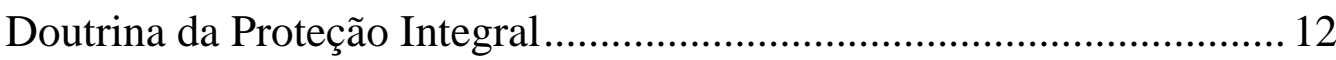

1.3 Reflexos da Constituição Cidadã no Direito pátrio.............................. 15

CAPÍTULO 2 - CONSIDERAÇÕES PRELIMINARES EM RELAÇÃO À DIGNIDADE SEXUAL DA INFANTO-JUVENTUDE 17

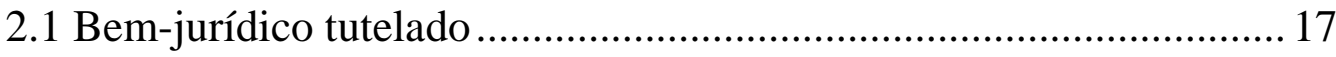

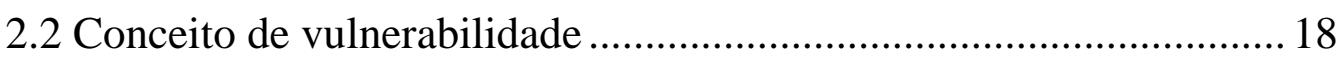

2.3 A mitológica busca da verdade real e a vitimização secundária do

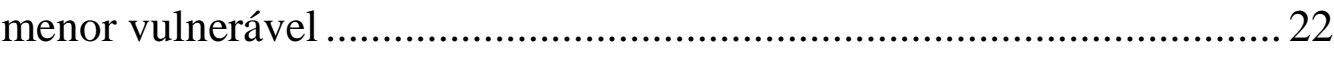

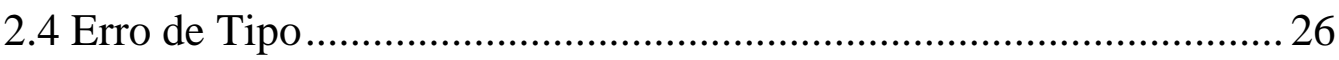

2.5 Compatibilidade ou não da presunção absoluta de vulnerabilidade com o instituto do erro de tipo e com o princípio da ofensividade ......... 29

CAPÍTULO 3 - A PROTEÇÃO JURÍDICA À DIGNIDADE SEXUAL

DA CRIANÇA E DO ADOLESCENTE ......................................................... 33

3.1 Tipos previstos no Código Penal ............................................................ 33

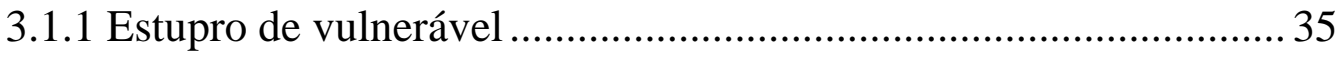

3.1.2 Uso de menor para satisfazer a lascívia de outrem .......................... 43

3.1.3 Satisfação de lascívia mediante presença de criança ou adolescente 46

3.1.4 Favorecimento da prostituição ou outra forma de exploração sexual de criança ou adolescente ou de vulnerável .............................................. 48

3.2 Tipos previstos no Estatuto da Criança e do Adolescente................... 55

3.2.1 Qualquer forma de participação na produção de cena de sexo explícito ou pornográfica envolvendo criança ou adolescente 59 
3.2.2 Comercialização de qualquer de registro com conotação sexual envolvendo criança ou adolescente 61

3.2.3 Distribuição ou divulgação de qualquer registro que contenha cena de sexo explícito ou pornográfica envolvendo criança ou adolescente .. 62 3.2.4 Aquisição ou posse de registro que contenha cena de sexo explícito ou pornográfica envolvendo criança ou adolescente. 65

3.2.5 Simulação do envolvimento de criança e adolescente em cena de sexo explícito ou pornográfica 68

3.2.6 Atrair criança com a finalidade de com ela praticar ato libidinoso 69 3.3 A ação penal nos crimes contra a dignidade sexual da infantojuventude .71

CAPÍTULO 4 - A PEDOFILIA.............................................................. 74

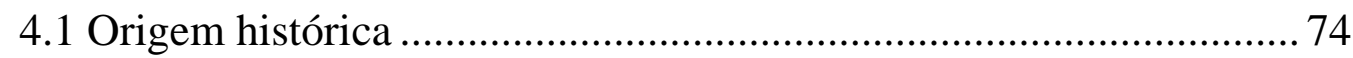

4.2 Conceito clínico e falácias terminológicas ........................................... 77

CAPÍTULO 5 - FORMAS DE COMBATE À VIOLÊNCIA SEXUAL CONTRA VULNERÁVEIS.......................................................................... 82

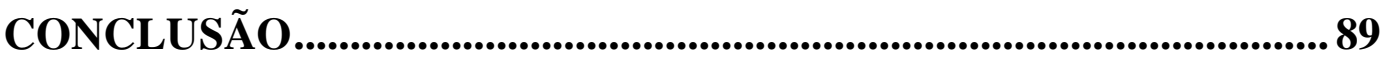

REFERÊNCIAS BIBLIOGRÁFICAS .......................................................92 


\section{LISTA DE ABREVIAÇÕES}

$\S$ - Parágrafo

Art. - Artigo

CP - Código Penal

CF - Constituição da República

ECA - Estatuto da Criança e do Adolescente

LCP - Lei de Contravenções Penais

ONG - Organização Não Governamental

Des. - Desembargador

Min. - Ministro

Rel. - Relator

REsp - Recurso Especial

STJ - Superior Tribunal de Justiça

STF - Supremo Tribunal Federal 


\section{INTRODUÇÃO}

O presente trabalho tem por objetivo analisar a proteção legal conferida pelo Direito Penal à dignidade sexual da criança e do adolescente. Antes, entretanto, será realizado panorama do tratamento dispensado à infância e juventude pelo ordenamento jurídico brasileiro, ressaltando-se a mudança de paradigma trazida pela Constituição Federal de 1988.

Nesse sentido, se examinarão as normas constitucionais afetas ao tema, bem como a evolução das correntes doutrinárias relativas à proteção do menor no Brasil, chegando-se à Doutrina da Proteção Integral.

Em seguida, virá à tona a vertente de proteção voltada à preservação da dignidade sexual das crianças e adolescentes, compreendida como verdadeira faceta do princípio da dignidade humana.

Em tal contexto, são expostos os tipos penais específicos atinentes ao tema, assim como os delitos previstos no ECA, apontando-se a complementariedade dos mesmos, sobretudo na sociedade digital atual.

Mais adiante, o tema da pedofilia é abordado por meio de comentários à sua origem histórica, elucidando-se, outrossim, o conceito clínico do termo, cuja correta compreensão é indispensável para se evitar as falácias advindas do emprego equivocado de terminologias.

Ainda em relação ao tópico, realiza-se análise quanto aos agressores sexuais da infanto-juventude, destacando-se que os mesmos não representam sinônimo à locução "pedófilo".

Por derradeiro, são assinaladas as formas de combate à violação carnal dos imberbes, assim como os desafios ainda enfrentados pelo Brasil na referida luta, sendo propostas soluções ao grave impasse, que se iniciam por meio do diagnóstico da dimensão do problema.

A escolha do objeto aqui tratado foi algo natural. 
Os crimes praticados contra os mais vulneráveis, sejam crianças, adolescentes ou demais sujeitos em situação de fragilidade, sempre me interessaram, em virtude do componente psicológico que leva o agente a optar por tais vítimas.

A partir da valiosa experiência obtida por meio de estágio na área criminal, passei a me interessar, ainda mais, pelos crimes sexuais perpetrados contra a infância e juventude, em razão dos motivos expostos abaixo.

A violência velada contida em tais delitos é algo peculiar, isto é, ao passo em que na maior parte dos crimes o agente delituoso é estranho à convivência da vítima, no que tange aos crimes sexuais contra inimputáveis, o agressor costuma estar inserido no meio de convivência da mesma, se abusando da confiança nele depositada para violar a lei.

Além disso, os sujeitos passivos em comento estão em momento peculiar de seu desenvolvimento biopsicossocial, o que justifica que os mesmos sejam detentores de direitos diferenciados, sendo a intervenção judicial com medidas especiais importante porque os jovens são incapazes de exigir seus direitos do mundo adulto.

Outro fator interessante é a dificuldade em mensurar os efeitos que o abuso sexual causa em suas vítimas, sendo certo que as repercussões dos crimes sexuais em muito extrapolam a esfera jurídica, sobretudo por violarem a própria dignidade da pessoa humana.

Em suma, esse ensaio pretende abarcar todos os elementos supracitados, analisando o arcabouço legal referente ao tema, bem como destacar que a exposição prematura à sexualidade, ainda mais forçada, impede a possibilidade de um amadurecimento saudável, o que reforça a imprescindibilidade de uma proteção efetiva a essa gama do corpo social. 


\section{CAPÍTULO 1 - PANORAMA DA PROTEÇÃO JURÍDICA CONFERIDA À CRIANÇA E AO ADOLESCENTE}

\subsection{Breve histórico do tratamento do "menor" no Brasil}

Atualmente as crianças e adolescentes gozam de situação privilegiada, sendo titulares de direitos amplamente reconhecidos nos ordenamentos jurídicos internacional e nacional, mas a realidade nem sempre foi assim.

Por muito tempo o Direito não demonstrou interesse pelos jovens, inexistindo normativa específica de proteção aos mesmos, o que refletia o desinteresse do Poder Público.

Não obstante, já no século XIX, estava prescrita a responsabilidade criminal dos menores de idade, haja vista que tanto o Código Penal de 1830 quanto o de 1890 previam medidas especiais aos jovens infratores, todas de caráter eminentemente repressivo.

Tais normativas se filiavam à Doutrina do Direito Penal do menor, a qual baseava a imputabilidade do impúbere na "pesquisa do discernimento", isto é, "imputava-se responsabilidade penal ao menor em função de uma pesquisa da sua consciência em relação à prática da ação criminosa"1.

A partir do século $\mathrm{XX}$, os sistemas legislativos passaram a se preocupar com a tutela da população infanto-juvenil, havendo, na Declaração de Genebra de $1924^{2}$, referência à necessidade de proporcionar à criança uma proteção especial.

No âmbito nacional, o primeiro Código Sistemático de Menores, o Decreto $\mathrm{n}^{\circ}$ 17.943-A, mais conhecido como Código Mello Mattos, foi promulgado em 12 de outubro de 1927.

\footnotetext{
1 JASMIM, Marcelo Gantus. Para uma História da Legislação sobre o Menor. In: Revista de Psicologia, $\mathrm{n}^{\circ}$ 4, 1986. p. 85.

${ }^{2}$ Disponível em: <http://www.un-documents.net/gdrc1924.htm>. Acesso em: 05 mai 2018.
} 
O projeto, idealizado por José Cândido de Albuquerque Mello Mattos, primeiro Juiz de Menores do Rio de Janeiro, representou uma iniciativa precursora, colocando o Brasil na vanguarda dos países latinoamericanos no tocante à assistência e proteção jurídica aos menores de dezoito anos.

O Decreto, embora inócuo em comparação à legislação presente, propôs verdadeiros avanços para o bem-estar do menor, eis que, dentre outras medidas, proibiu que o menor de 14 (quatorze) anos fosse submetido a processo criminal de qualquer espécie, bem como limitou a idade mínima de trabalho a 12 (doze) anos e vedou que o menor de 18 (dezoito) anos trabalhasse no período noturno.

Ademais, o Código de Menores de 1927, ao determinar a medida aplicável, levava em consideração o estado físico, mental e moral da criança, e ainda a situação social, moral e econômica dos pais.

Já na década de 60, surgem as Fundações do Bem-Estar do Menor FUNABEM E FEBEM - cuja finalidade inicial era formular diretrizes para a política nacional de atendimento a esse segmento populacional, tendo como proposta a substituição da repressão e segregação por programas educacionais.

Entretanto, o projeto desvirtuou-se de sua concepção inicial, levando as Fundações a atuar diretamente como agentes de correção. As instituições mostraram-se inadequadas: além das precárias instalações, os maus-tratos aplicados aos menores impediam-nas de cumprirem a função de reabilitação. Extinguiram-se em 1990.

Tendo vigorado por mais de dez anos, o novo Código de Menores de 1979 (Lei $\mathrm{n}^{\circ}$ 6.697/79) trouxe à baila uma nova corrente doutrinária que substituiria a anterior. 
Nesse sentido, foi introduzida a Doutrina Jurídica de Proteção ao Menor em Situação Irregular, a qual deu vez a uma nova área de especialização das ciências jurídicas: o Direito do Menor.

Tal ramo propunha uma associação entre a Sociologia e o Direito, de modo a proporcionar uma melhor compreensão das necessidades estruturais e afetivas dos menores e, assim, promover sua harmonia biopsicossocial.

Embora possuísse olhar voltado ao bem-estar do menor, a doutrina supramencionada era incutida de subjetivismo, tendo em conta a grande discricionariedade conferida ao juiz quando da aplicação do Código, o que acabava por colocar as crianças e adolescentes a mercê da boa vontade de seu julgador.

Tal linha de pensamento não mais vigora na legislação pátria, tendo em conta que muitos avanços ocorreriam na virada da década...

\subsection{Mudança de paradigma promovida a partir da Constituição de 1988: Doutrina da Proteção Integral}

Em 1989 foi aprovada a "Convenção sobre os Direitos da Criança" pela ONU, impondo a todos os Estados signatários a promoção de mudanças em suas Constituições, de modo a adequar a ordem jurídica interna às normas internacionais.

Entretanto, o Brasil, mesmo antes da Convenção entrar em vigência, já havia introduzido uma proteção efetiva às crianças e aos adolescentes, estando à frente das outras nações. Um ano antes da aprovação e efetivação do documento, o país antecipou as disposições da Normatização Internacional, incluindo-as na Constituição de 1988. Na época, em votação na Assembléia Nacional Constituinte, consagrou-se na Constituição Cidadã um capítulo destinado à infância e juventude.

Nessa esteira, cabe ressaltar o art. $227 \mathrm{da} \mathrm{CF}$, o qual é reconhecido na comunidade internacional como síntese da Convenção da ONU, ao 
declarar os direitos especiais da criança e do adolescente como dever da família, da sociedade e do Estado, além de colocá-los a salvo de toda forma de negligência, discriminação, exploração, violência, crueldade e opressão.

A referida norma reconhece inúmeros direitos às crianças e adolescentes, e afirma a condição especial dos mesmos, por estarem passando por um período de transição pessoal, crucial em seu desenvolvimento biopsicossocial, não podendo prover sua sobrevivência sozinhos nem responder inteiramente por seus atos e a eventuais acusações.

Importante frisar a relevância do emprego da palavra "direito", pois isso demonstra uma verdadeira mudança de paradigma em relação ao tratamento jurídico conferido à população infanto-juvenil.

A utilização de tal termo leva ao reconhecimento da criança e do adolescente como "sujeitos de direitos exigíveis" com base nas leis, deixando os mesmos de serem tratados como objetos passivos. Eles deixam de ser vistos primordialmente como portadores de vulnerabilidades ou carências, passando-se a considerá-los não como pessoas que têm apenas "necessidades", mas sim como titulares de direitos juridicamente protegidos. Os jovens tornam-se parte do interesse do arcabouço legal, que deve assegurar o cumprimento e manutenção do que lhes reserva a lei. Assim, tornam-se independentes da "boa vontade" alheia, não estando mais à mercê de terceiros.

Nesse contexto, em 1990, uma mobilização social inédita levou à aprovação da lei $n^{\circ}$ 8.069/90, denominada como o "Estatuto da Criança e do Adolescente", que veio para regulamentar os dispositivos constitucionais de 88 .

Trata-se, o Estatuto, de um conjunto de princípios e medidas anunciado como revolucionário, por alterar imensamente as relações jurídicas referentes aos jovens, bem como por ser o primeiro diploma legal no mundo a sistematizar os princípios do Direito da Criança e do Adolescente. 
A existência do ECA deve-se a uma revoada cívica que contou com o apoio de mais de 1.400 .000 (um milhão e quatrocentas) pessoas na apresentação de duas emendas populares. Tal lei revogou e substituiu o antigo Código de Menores de 1979, como também outras leis referentes à condição judicial do menor. O ECA almejava avanços na matéria, aprimorando o sistema jurídico referente à quase metade da população brasileira - afinal, as crianças e os adolescentes são mais de 70 (setenta) milhões dos habitantes do país.

E, nesse novo arcabouço legal, a diretriz primordial seria a "Doutrina da Proteção Integral", que prega uma total cobertura da criança e do adolescente em suas diversas necessidades, institucionalizando ampla gama de direitos, a partir do reconhecimento de sua condição especial.

Nesse sentido, a Doutrina da Proteção Integral considera os jovens como pessoas em condição de desenvolvimento e por isso acredita que seja necessária a existência de direitos especiais e específicos. Tal corrente defende o reconhecimento universal dos direitos de todas as crianças e adolescentes, de modo que o Direito de cada país deve estar em consonância com as normas internacionais, garantindo que as cláusulas aprovadas em 1985, na Assembléia- Geral da ONU, sejam respeitadas. Em tais regras, não se inclui somente o aspecto "penal" do ato praticado pela ou contra a criança, mas englobam-se também as necessidades destas. Leva-se em consideração o direito à vida, à educação, à saúde e à liberdade das pessoas até 18 (dezoito) anos.

Há o reconhecimento, também, da existência de um Direito Fundamental à Infância, tendo como fundamento subjetivo "a importância para o indivíduo, sua formação e desenvolvimento de sua personalidade"3, bem como um fundamento objetivo:

\footnotetext{
3 ARRUDA, Kátia Magalhães. O Trabalho de Crianças no Brasil e o Direito Fundamental à Infância. In: Dos Direitos Humanos aos Direitos Fundamentais. 1997. p. 105.
} 
Face ao interesse público, necessidade social e até a evolução da comunidade na compreensão de resguardar um período imprescindível ao ser humano e que, após ultrapassado, jamais poderá ser resgatado ${ }^{4}$.

É exatamente tal direito fundamental à infância que é roubado da criança e do adolescente com a iniciação sexual precoce e forçada.

\subsection{Reflexos da Constituição Cidadã no Direito pátrio}

Os novos ares trazidos pela Lei Maior não se restringiram à ordem constitucional, tendo, a Doutrina da Proteção Integral, repercutido, também, na legislação infraconstitucional.

Nessa ambiência, conforme destacado no capítulo retro, é que surgiu o Estatuto da Criança e do Adolescente, promulgado apenas um ano após a entrada em vigência da Carta Política.

Em outras palavras, as disposições elaboradas pela Constituinte de 1987, no que tange à infanto-juventude, serviram como norma programática a ressoar no sistema jurídico-político como um todo.

Com efeito, cumpre salientar que tal modalidade de norma constitucional possui o escopo de impor ao Estado o "cumprimento de certos fins, a consecução de certas tarefas de forma a realizar certos princípios ou objetivos, fazendo surgir, por consequência, a necessária proteção dos interesses subjetivos que daí dimanam"5.

Nada obstante, segundo leciona o eminente Luis Roberto Barroso, as normas constitucionais programáticas geram o efeito imediato de revogar os atos normativos pretéritos que disponham em sentido colidente com o princípio que substanciam, bem como carreiam um juízo de inconstitucionalidade para os atos normativos futuros ${ }^{6}$.

\footnotetext{
${ }^{4}$ ARRUDA, 1997, p. 105.

5 FERRARI, Regina Maria Macedo Nery. Normas Constitucionais Programáticas Normatividade, Operatividade. $1^{a}$ ed., São Paulo: Ed. Revista dos Tribunais, 2001. p. 157.

${ }^{6}$ BARROSO, Luis Roberto. O Direito Constitucional e Eficácia das Normas. 9a ed., Rio de Janeiro: Ed. Renovar, 2009. p. 113.
} 
O efeito do art. 227 da Lei Básica, em tudo e por tudo, foi muito além.

A Doutrina da Proteção Integral nele contida, enquanto rede principiológica, acarretou na eclosão de aparato legislativo específico de tutela aos menores de idade, assim considerados como aqueles com 19 (dezenove) anos incompletos, conforme o art. $2^{\circ}$ da Lei 8.069/1990.

O Estatuto adveio com uma ampla gama de direitos e garantias exigíveis por seus titulares, haja vista que, de acordo com o art. $3^{\circ}$ do indigitado mandamento:

A criança e o adolescente gozam de todos os direitos fundamentais inerentes à pessoa humana, sem prejuízo da proteção integral de que trata esta Lei, assegurando-se-lhes, por lei ou por outros meios, todas as oportunidades e facilidades, a fim de lhes facultar o desenvolvimento físico, mental, moral, espiritual e social, em condições de liberdade e de dignidade.

O Código, outrossim, impôs obrigação erga omnes aos cidadãos brasileiros, eis que, aos mesmos, recai o dever de:

Art. 18. (...) velar pela dignidade da criança e do adolescente, pondo-os a salvo de qualquer tratamento desumano, violento, aterrorizante, vexatório ou constrangedor.

Ante o exposto, observa-se que o muro protetivo erigido em torno dos jovens é vasto e extenso, abrangendo inúmeras vertentes, a saber - à guisa de ilustração -, o direito à vida, à saúde, à educação, ao lazer, ao respeito e à dignidade; estando os mesmos a salvo de qualquer modo de exploração, violência e crueldade.

Dentre as diversas possíveis formas de abuso juvenil, o objeto da presente dissertação é a exploração sexual dos vulneráveis, tema que passará a ser o enfoque deste texto. 


\section{CAPÍTULO 2 - CONSIDERAÇÕES PRELIMINARES EM RELAÇÃO À DIGNIDADE SEXUAL DA INFANTO- JUVENTUDE}

\subsection{Bem-jurídico tutelado}

Sob o prisma garantista, incutido no princípio da intervenção mínima, o Direito Penal corresponde à ultima ratio, sendo, portanto, voltado à proteção subsidiária de bens-jurídicos, exatamente por se tratar da "arma mais drástica do arsenal jurídico", nas palavras do saudoso Roberto Lyra.

Bem-jurídico, por sua vez, de acordo com Claus Roxin, pode ser conceituado como as "circunstâncias dadas ou finalidade que são úteis para o indivíduo e seu livre desenvolvimento no marco de um sistema social global"'.

Dessa forma, observa-se a nítida fluidez na valoração do que vem a constituir um bem fundamental, tendo em vista que a seleção política e constante de tais baluartes está intrinsicamente ligada aos padrões morais, sociais e culturais da época.

Por derradeiro, segundo os ensinamentos de Figueiredo Dias, a noção de bem-jurídico penal decorre da Constituição, eis que, uma vez inseridos na Lei Maior, os bens do sistema social passam por uma mutação e se consolidam em bens-jurídicos dignos de tutela penal, por meio da ordenação axiológica jurídico-constitucional ${ }^{8}$.

Nesse diapasão, a eleição dos bens-jurídicos aptos a invocar a chancela criminal deve ser feita com esteio nos valores que irradiam da

\footnotetext{
${ }^{7}$ ROXIN, Claus. Derecho Penal: parte general. t.1, Madrid: Civitas, 1997. p. 51.

${ }^{8}$ Jorge de Figueiredo Dias."Questoes fundamentais de direito penal revisitadas". São Paulo: RT, 1999, p.66.
} 
Carta Magna, de modo que o direito penal seja o direito constitucional aplicado, conforme receitava Roxin?

No cosmo de bens-jurídicos tutelados pela seara penal, existem delitos voltados a combater os abusos sexuais infantis. Tais tipos penais são voltados à proteção da dignidade sexual da vítima, bem como do livre e sadio desenvolvimento da personalidade sexual da infanto-juventude.

Procura-se assegurar o progresso não desvirtuado da personalidade do menor, para que o mesmo evolua livre de traumas psicológicos e, posteriormente, possa, de modo sereno e consciente, eleger seu comportamento sexual, inclusive no que toca à sua opção sexual. Quanto a esse ponto, permita-se colacionar Muñoz Conde, para quem:

Mais que a liberdade do menor ou incapaz, que obviamente não existe nesses casos, pretende-se, na hipótese do menor, proteger sua liberdade futura, ou melhor dito, a normal evolução e desenvolvimento de sua personalidade, para que quando seja adulto decida livremente o seu comportamento sexual ${ }^{10}$.

Noutro giro, é possível afirmar que tal gama de tipicidade é voltada a resguardar os direitos humanos universais na espécie, haja vista que o abuso sexual infanto-juvenil lesa os direitos fundamentais dessa parcela da coletividade, ultrapassando os limites e regras culturais, sociais e legais.

Trata-se de crime que não se limita aos rastros físicos imediatos que gera, dando azo a efeitos muito mais graves e que se protraem no tempo, ecoando e atingindo a própria alma das jovens vítimas.

\subsection{Conceito de vulnerabilidade}

Conforme destacado acima, em se tratando de crime libertinoso contra crianças e adolescentes, não se pode elencar como bem-jurídico tutelado a liberdade sexual.

\footnotetext{
${ }^{9}$ ROXIN, 1997, p. 51.

${ }^{10}$ CONDE, Francisco Muñoz. Direito Penal - Parte Especial. $12^{\mathrm{a}}$ ed., Valência: Tirant lo Blanch, 1999. p. 196.
} 
Desta assertiva dimana todo o conceito de vulnerabilidade.

Nessa esteira, o indigitado valor não incorpora o universo de bensjurídicos resguardados por delitos de tal natureza exatamente por que o sujeito passivo não possui plena disponibilidade do exercício dessa liberdade, o que, por conseguinte, caracteriza a vulnerabilidade, senão vejamos:

Nos crimes sexuais que envolvem crianças e adolescentes, mais do que a liberdade sexual, são violadas também a integridade física, psíquica e a dignidade da pessoa humana, pois a sexualidade em crianças e adolescentes, jovens cujas personalidades ainda se encontram em desenvolvimento, não se pode, consequentemente, falar em 'liberdade sexual' ou autonomia para determinar seu comportamento no âmbito sexual ${ }^{11}$.

Em outros termos, o menor vulnerável está em fase de desenvolvimento biopsicossocial, o que engloba as esferas física, mental, moral, espiritual e social, não sendo possível, portanto, que o mesmo eleja livremente suas ações.

Insta salientar, também, que por não serem plenamente capazes de se autodeterminar, os vulneráveis não têm o discernimento necessário para a prática de determinados atos, sobretudo os de cunho sexual, tampouco podem oferecer efetiva resistência.

Assim entendendo, tanto a seara penal quanto a cível conferiram tratamento díspar a essa parcela da população, tendo como enfoque o critério etário.

Brevemente, cumpre assinalar que o Código Civil previu, em seu art. $3^{\circ}$, que os menores de 16 (dezesseis) anos são absolutamente incapazes de exercer os atos da vida civil, sob pena de nulidade absoluta, ao passo que aos menores de 18 (dezoito) anos recai a incapacidade relativa, norma consubstanciada no art. $4^{\circ}$ do mesmo diploma legal.

${ }^{11}$ BITENCOURT, Luciane Potter. Vitimização secundária infanto-juvenil e violência sexual intrafamiliar. Rio de Janeiro: Lumen Juris, 2009. p. 71-72. 
Seguindo lógica análoga, o Estatuto Penal dispôs que os menores de 18 (dezoito) anos são inimputáveis, ou seja, não incidindo sobre eles, quando autores de fato contrário à lei, as normas previstas na indigitada normativa, tendo em vista estar ausente um dos elementos constituintes da culpabilidade, a saber, a imputabilidade.

Entretanto, as previsões penais se aplicam aos menores de idade na condição de sujeitos passivos de delitos, havendo, inclusive, tipos penais específicos destinados a eles, os quais serão tratados mais adiante nesse ensaio.

Por fim, importante destacar que o legislador pecou na elaboração dos referidos fatos típicos, acarretando grande confusão referente à idade do vulnerável. Isso porque ora refere-se a menor de 14 (quatorze) anos, ora a menor de 18 (dezoito), sem traçar grandes ponderações.

Diante da aparente incongruência narrada acima, a jurisprudência majoritária passou a entender que, embora não tenha o legislador sido expresso, há duas espécies de vulneráveis.

Nesse sentido, por um lado, haveria a vulnerabilidade absoluta e, portanto, presumida, a reger crimes carnais contra menores de 14 (quatorze) anos, e, por outro, a relativa, no tocante a menores de 18 (dezoito) anos.

Tal linha de interpretação recebeu, recentemente, respaldo do Superior Tribunal de Justiça, eis que a Terceira Seção da Corte da Cidadania aprovou, em 25 de outubro de 2017, enunciado que espelha ipsis litteris a assertiva acima arrazoada. Confira-se, na íntegra, o verbete:

Súmula 593. O crime de estupro de vulnerável configura-se com a conjunção carnal ou prática de ato libidinoso com menor de 14 anos, sendo irrelevante o eventual consentimento da vítima para a prática do ato, experiência sexual anterior ou existência de relacionamento amoroso com o agente.

Nada obstante, cumpre asseverar que tal posicionamento não é uníssono na Doutrina, havendo quem considere retrógrado, nos tempos atuais, se estabelecer uma presunção iuris et iuris de vulnerabilidade, 
sobretudo sob a ótica dos princípios constitucionais da intervenção mínima do direito penal, do contraditório e da presunção de inocência.

Ademais, pondera-se que o dispositivo em análise estaria dissociado da realidade social, eis que, com a exposição da juventude aos meios de comunicação e a propagação de informações, o desenvolvimento intelectual e a capacidade cognitiva das crianças e adolescentes estaria mais precoce.

Os paladinos da concepção afivelada acima propõem a relativização da vulnerabilidade, de modo que a mesma seja sempre aferida casuisticamente, levando-se em conta a maturidade sexual e desenvolvimento mental do suposto ofendido, para que só se reputem como vulneráveis aqueles que, efetivamente, não possuam o discernimento intrínseco à prática sexual.

Certo é que se está diante de colisão entre princípios de estatura constitucional, em relação aos quais não há hierarquia, conforme já pontuado pela Suprema Corte no julgamento da ADI 815/DF, em que restou assentado "a incompatibilidade da tese da hierarquia entre as normas constitucionais originárias com o sistema de Constituição rígida vigente no Brasil" $" 12$.

Diante de tal fenômeno, há que ser invocada a técnica de ponderação, a qual permite a solução de tensões normativas envolvendo valores ou opções políticas, insuperáveis pelas formas hermenêuticas tradicionais.

Enquanto as regras são aplicadas pela subsunção, comandada pelo critério "tudo ou nada", os princípios, por sua vez, são sopesados caso a caso a partir de avaliação voltada a definir, in concreto, qual deve prevalecer.

\footnotetext{
12 Disponível em:

<http://www2.stf.jus.br/portalStfInternacional/cms/verConteudo.php?sigla=portalStfJurisprudenci a_pt_br\&idConteudo $=185145 \& \operatorname{modo}=\mathrm{cms}>$. Acesso em: 20 mai. 2018.
} 
Conforme proposto por Robert Alexy ${ }^{13}$, a ponderação deve maximizar a realização dos princípios em questão sem recorrer à invalidação de um deles, sendo a metodologia vantajosa exatamente por impedir o esvaziamento dos direitos fundamentais em jogo.

Dessa forma, no presente embate, em que se tem, por um lado, os princípios de direito penal espalhados pela Carta Magna e, por outro, a Doutrina da Proteção Integral, consubstanciada em norma constitucional específica, cumpre almejar interpretação que permita a preservação de todos os valores em cheque.

Nessa esteira, seria possível compatibilizar os preceitos em questão caso se limitasse a presunção absoluta de vulnerabilidade aos menores de 12 (doze) anos, ou seja, às crianças, de modo que, em relação aos adolescentes, houvesse presunção relativa, dependendo, portanto, a incidência do tipo, da comprovação da efetiva condição de vulnerável do sujeito passivo.

Frise-se que tal proposição preservaria o sentido do art. 227 da CF, eis que manteria a presunção de vulnerabilidade em relação a todos os menores de 18 (dezoito) anos, apenas modulando o nível de contraditório tolerado, de modo a privilegiar, também, os princípios penais da ampla defesa e da presunção de inocência, potencializados a partir da admissão de prova em contrário no que tange à fragilidade quando os fatos envolverem adolescente.

\subsection{A mitológica busca da verdade real e a vitimização secundária do menor vulnerável}

A despeito das críticas expostas previamente, elogios devem ser prestados à preocupação do legislador penal com o bem-estar do menor de 14 (quatorze) anos.

\footnotetext{
${ }^{13}$ ALEXY, Robert. Teoria de los Derechos Fundamentales. Madri: Centro de Estúdios Políticos y Constitucionales, 2001. p. 112.
} 
Isso porque, ao consagrar a infanto-juventude como merecedora de tratamento especial do Poder Público, bem como da lei, o Congresso Nacional combateu o descaso histórico das autoridades repressoras para com esse setor da população.

No ensejo, cumpre tecer alguns comentários em relação a outra agressão imposta àqueles, agora e finalmente, reconhecidos como vulneráveis, qual seja, a vitimização secundária decorrente da violência estatal.

A vitimização secundária dos menores vítimas de abuso sexual é fenômeno complexo, tanto do ponto de vista jurídico como criminológico, relacionado à posição da criança ou adolescente como testemunha no processo penal.

O ciclo de brutalidade iniciar-se-ia com a vitimização primária desinente da violência sexual praticada em face do infanto-juvenil, seguindo-se da referida vitimização secundária, que dimanaria do próprio sistema de justiça penal e da opressão institucional inerente ao estigma procedimental-investigatório.

Tal evento ocorre quando o ofendido é subjugado à categoria de mero objeto de investigação e meio de prova, sendo tratado como acervo probatório processual, inquirido de forma insensível, ritualística e abrutalhada, o que culmina na amplificação da agressão já sofrida.

Em nenhuma hipótese, tem o Estado, mormente já tendo falhado na função preventiva de combate a esse tipo de criminalidade, o direito de revitimizar jovens sob o pretexto da busca da verdade real.

No azo, cumpre assinalar que se cuida de verdadeira criatura mitológica, conforme bem destacou Aury Lopes Junior, ao gizar que: 
Há que se descobrir a origem e a finalidade do mito da verdade real: nasce na inquisição e, a partir daí, é usada para justificar os atos abusivos do Estado, na mesma lógica de que "os fins justificam os meios"14.

De forma alguma pode a máxima Maquiavélica imperar no Estado Democrático de Direito.

$\mathrm{Na}$ oportunidade, cumpre trazer à baila voto da lavra do Eminente Ministro Félix Fischer, que, ao analisar remédio heroico impetrado, considerou o quanto se segue a respeito do indigitado princípio:

(...) a concepção havida, inclusive, por muitos, como ultrapassada, daquilo que vem a ser verdade real, não é aceita pela dogmática moderna. Jorge Figueiredo Dias (in "Processo Penal", ed. 1974, reimpressão de 2004, Coimbra Editora) alerta que "...a verdade material que se busca em processo penal não é o conhecimento ou apreensão absoluta de um acontecimento, que todos sabem escapar à capacidade do conhecimento humano; tanto mais que aqui intervém, irremediavelmente, inúmeras fontes de possível erro..."(p. 204). Ensina que a assim denominada verdade material há de ser tomada em duplo sentido: "no sentido de uma verdade subtraída à influência que, através do seu comportamento processual, a acusação e a defesa queiram exercer sobre ela; mas também no sentido de uma verdade que, não sendo "absoluta" ou "ontológica", há de ser antes de tudo uma verdade judicial , prática e, sobretudo, não uma verdade obtida a todo preço mas processualmente válida"15.

Nesse giro, conforme afivelado acima, a apreensão completa e irrestrita do delito é uma meta onírica, intangível na essência, de modo que tal cruzada não pode, absolutamente, legitimar a inquirição invasiva das pequenas vítimas, eis que tal insensibilidade da justiça criminal, somatizada à vulnerabilidade natural dos menores e cumulada à peculiar circunstância de abuso, pode inviabilizar a superação do trauma, bem assim culminar no sentimento de desamparo e descrédito nas instituições estatais.

Entretanto, inegável que o depoimento das crianças e adolescentes é essencial à instrução, até mesmo para assegurar um contraditório farto e profuso, logo, se deve ponderar os interesses em jogo, de forma a dar a maior efetividade aos princípios em embate, ambos de estatura

\footnotetext{
${ }^{14}$ LOPES JUNIOR, Aury. Introdução Crítica ao Processo Penal. $4^{\mathrm{a}}$ ed., Rio de Janeiro: Lumen Juris Editora, 2006. p. 273.

${ }^{15}$ STJ, Habeas Corpus n. 155.149/RJ, Rel. Ministro Félix Fischer, publicado em 11/06/2010. p. 193-194.
} 
constitucional, havendo, por um lado, o direito à ampla defesa do eventual acusado e, por outro, o direito à dignidade inerente a qualquer ser humano.

Urge, portanto, por uma troca de paradigma do sistema processual penal, sendo essencial que crianças e adolescentes, vítimas de violência sexual, sejam vislumbradas, não como objeto de investigação e indício de materialidade ambulante, mas, sim, como sujeitos de direitos, o que lhes foi afiançado pela inquebrantável Carta Cidadã.

Dessa forma, há que se aprimorar o procedimento investigatório tradicional, reconhecendo a manifesta necessidade de uma abordagem interdisciplinar para evitar a vitimização secundária. Nesse cenário, seria imprescindível a atividade preliminar de preparação das vítimas para a audiência, com a participação de militantes de diversas áreas, tais como terapeutas, assistentes sociais, psicólogos e, até mesmo, psiquiatras.

Além do trabalho preparatório, os indigitados técnicos também devem intermediar a interlocução nas audiências, de modo que os questionamentos formulados pelos atores do processo sejam direcionados a esses, que, em recinto contíguo à sala de audiência, repassariam as indagações às vítimas, sempre em linguagem coloquial e enquanto brincam com as mesmas.

O que se objetiva é diluir as formalidades forenses, estarrecedoras sob o prisma leigo, bem como tolher a agressividade intrínseca aos questionamentos pertinentes aos fatos delituosos, em suma, ocultando que se trata de inquisição de qualquer natureza.

Fora as sugestões trazidas à baila, em prol do respeito à dignidade da pessoa humana, também é vital a conscientização do Estado, ora representado pelo Poder Judiciário e pelo Ministério Público, devendo as entidades em apreço compreender que, na seara em comento, carecem reciclar sua cultura de trabalho, procurando meios outros de se aproximar da almejada verdade real, seja através do aprimoramento dos meios 
investigativos tradicionais, seja investindo em técnicas mais avançadas, ou em mão de obra de escol.

Tudo desde que não revitimizem quem já padeceu com a primeira violência, que a própria Administração foi incapaz de impedir.

\subsection{Erro de Tipo}

O erro de tipo assume especial relevância no que diz respeito aos crimes de cunho sexual perpetrados contra menores, eis que, a depender da conjuntura, o autor do fato pode desconhecer a menoridade da outra parte, assim, não lhe sendo possível vislumbrá-la como vítima.

O instituto está consubstanciado no art. 20 da normativa penal, cujo parágrafo primeiro também traz a figura das descriminantes putativas, senão vejamos:

O erro sobre elemento constitutivo do tipo legal de crime exclui o dolo, mas permite a punição por crime culposo, se previsto em lei.

$\S 1^{\circ}$ - É isento de pena quem, por erro plenamente justificado pelas circunstâncias, supõe situação de fato que, se existisse, tornaria a ação legítima. Não há isenção de pena quando o erro deriva de culpa e o fato é punível como crime culposo.

Antes de adentrar exame acurado da norma assinalada, importante frisar que existem duas modalidades de erro de tipo, a saber, o essencial e o acidental, sendo o último irrelevante para o debate ora cotejado, pois, conforme destacou Capez ${ }^{16}$, a sua incidência...

Não impede a apreciação do caráter criminoso do fato. $O$ agente sabe perfeitamente que está cometendo um crime. Por essa razão, é um erro que não traz qualquer consequência jurídica: o agente responde pelo crime como se não houvesse erro.

${ }^{16}$ CAPEZ, Fernando. Direito Penal Simplificado: Parte Geral. 15 a ed., São Paulo: Saraiva, 2012. p. 111 . 
Em contrapartida, o erro de tipo essencial impede que o agente assimile o caráter criminoso de sua conduta, logo, possuindo extrema pertinência face aos efeitos jurídicos que acarreta.

O erro essencial significa que o sujeito está enganado acerca de elemento constitutivo do tipo, apreendendo uma falsa percepção da realidade, de modo que inexiste vontade consciente de produzir determinado resultado, o que exclui, por conseguinte, o dolo.

Ou seja, a incidência do erro fundamental sempre culminará na exclusão do dolo, entretanto, as implicações legais serão moduladas a depender da escusabilidade ou não do erro em apreço.

Nesse sentido, há duas subespécies contidas na modalidade dissertada, isto é, o erro elementar pode ser inevitável ou evitável, sendo tal aferição feita com base em exercício retrospectivo voltado a averiguar a possibilidade de o erro ter sido refreado caso empregados critérios razoáveis de prudência.

Por um lado, se o erro, uma vez aplicados parâmetros de cautela, fosse vencível, o dolo, conforme já ressaltado, restará suprimido, entretanto, subsistirá a culpa, de sorte que o indivíduo será punido, a título culposo, desde que o crime em questão assim o franqueie.

Do contrário, isto é, em não havendo previsão na norma de tipo culposo correspondente, a conduta será atípica, haja vista que o Código Penal assenta, em seu art. 18, inciso II, parágrafo único, a regra da excepcionalidade do crime culposo, ao dispor que "salvo os casos expressos em lei, ninguém pode ser punido por fato previsto como crime, senão quando o pratica dolosamente".

Por outro lado, aquele que incida em erro que, mesmo depois de adotadas medidas de vigilância, se revele insuperável, não responderá por nada, sendo hipótese de atipicidade da conduta. 
Tais distinções minuciosas de caráter técnico assumem menor significância no que tange aos delitos abordados no presente ensaio, tendo em vista que tais tipos penais não tipificam a modalidade culposa, logo, desimportante a inevitabilidade ou não do erro.

Nesse diapasão, estando o autor do delito de natureza sexual contra a infanto-juventude acometido por erro essencial, seja evitável ou não, a conduta estará acobertada pela atipicidade, ante a ausência de previsão legal de correligionários culposos.

Por derradeiro, permita-se colacionar manifestação pretoriana do Superior Tribunal de Justiça, que, ao analisar Recurso Especial, esposou tese idêntica à afivelada supra. Veja-se:

CRIMINAL. ART. 244-A DO ESTATUTO DA CRIANÇA E DO ADOLESCENTE. CONFIGURAÇÃO. CLIENTE OU USUÁRIO DO SERVIÇO PRESTADO PELA INFANTE JÁ PROSTITUÍDA E QUE OFERECE SERVIÇOS. NÃO ENQUADRAMENTO NO TIPO PENAL. DESCONHECIMENTO DA IDADE DA VÍTIMA. AUSÊNCIA DE DOLO. RECURSO DESPROVIDO.

I. O crime previsto no art. 244-A do ECA não abrange a figura do cliente ocasional, diante da ausência de "exploração sexual" nos termos da definição legal.

II. Hipótese em que o réu contratou adolescente, já entregue à prostituição, para a prática de conjunção carnal, o que não encontra enquadramento na definição legal do art. 244-A do ECA, que exige a submissão do infante à prostituição ou à exploração sexual.

III. Caso em que a adolescente afirma que, arguida pelo réu acerca de sua idade, teria alegado ter 18 anos de idade e ter perdido os documentos, o que afasta o dolo da conduta do recorrido.

IV. A ausência de certeza quanto à menoridade da "vítima" exclui o dolo, por não existir no agente a vontade de realizar o tipo objetivo. $E$, em se tratando de delito para o qual não se permite punição por crime culposo, 
correta a conclusão a que se chegou nas instâncias ordinárias, de absolvicãa do réu. V. Recurso desprovido ${ }^{17}$. (grifo nosso).

Por fim, indispensável atentar à ratio legis por trás do erro essencial, sendo nítido que o legislador almejou impedir a penalização do cidadão sem que haja previsibilidade da condição pessoal da vítima, já que em tal cenário não há que se falar em dolo ou culpa, não devendo incidir, portanto, a seara penal.

Conclusão díspar representaria o triunfo da responsabilidade objetiva, a qual não se coaduna com o Direito Penal Democrático. Frise-se, responsabilidade, em matéria criminal, não se presume.

Eventuais considerações quanto à possibilidade de aplicação de dolo eventual aos crimes sexuais serão tratadas no item 3.1.1.

\subsection{Compatibilidade ou não da presunção absoluta de vulnerabilidade com o instituto do erro de tipo e com o princípio da ofensividade}

Renomados lecionadores assinalam que o direito penal da culpa é inconciliável com presunções de fato, não devendo, portanto, o ramo criminal operar com base em suposições. Argumentam ser imprescindível a análise da culpa em sentido amplo do agente, a qual deverá ser afastada, impreterivelmente, caso o indivíduo esteja incurso em erro de tipo, sob pena de se incorrer em responsabilidade objetiva, a qual não é compatível com o Direito Penal Liberal, eis que a culpa subjetiva constitui a única modalidade de autoria capaz de provocar efeitos penais.

Todavia, não se pode afirmar que a presunção absoluta de vulnerabilidade vá de encontro com a figura do erro de tipo.

\footnotetext{
17 STJ, Recurso Especial nº. 884333/SC, QUINTA TURMA, Relator: Ministro GILSON DIPP, Data de Julgamento: 10/05/2007, Data de Publicação: DJ 29/06/200, p. 708.
} 
A partir de uma interpretação harmonizadora das fontes do direito, é possível assimilar que mesmo sendo a vítima menor de quatorze anos cenário de incidência da presunção juris et de jure -, a conduta só será penalmente relevante se o agente tiver consciência da condição especial do jovem, caso contrário, haverá exclusão do dolo e, por conseguinte, da tipicidade.

Curioso destacar que a tese pretoriana fixada na Súmula 593 do Tribunal da Cidadania não se traduz em novidade, eis que a Terceira Seção, responsável pela aprovação do enunciado, já havia empregado fundamentação idêntica em sede de recurso repetitivo, tendo o Ministro Rogério Schietti esposado esse exato posicionamento ao analisar o crime de estupro de vulnerável. Veja-se:

Por se cuidar de julgamento de Recurso Especial sob o rito dos recursos repetitivos (art. 543-C), proponho a seguinte tese, a derivar das conclusões extraídas deste julgamento:

Para a caracterização do crime de estupro de vulnerável previsto no art. 217-A, caput, do Código Penal, basta que o agente tenha conjunção carnal ou pratique qualquer ato libidinoso com pessoa menor de 14 anos. O consentimento da vítima, sua eventual experiência sexual anterior ou a existência de relacionamento amoroso entre o agente e a vítima não afastam a ocorrência do crime ${ }^{18}$.

A construção jurisprudencial alhures, ao desconsiderar as condições pessoais de cada vítima, in concreto, é antagônica, agora sim, com o princípio da ofensividade e da lesividade, cuja aplicação resultaria na primazia da presunção relativa, isto é, da aferição casuística da efetiva vulnerabilidade da vítima, a ser realizada a partir de avaliação do grau de discernimento do impúbere em torno da conduta incriminada.

Diversos doutrinadores defendem a relativização da presunção de vulnerabilidade, dentre eles $\mathrm{Nucci}^{19}$ e Bittencourt ${ }^{20}$, aduzindo, para tanto,

\footnotetext{
${ }^{18}$ STJ, Recurso Especial (repetitivo), nº. 1.480.881/PI, Terceira Seção, Rel. Ministro Rogério Schietti, julgamento em: 27/08/2015, Data de Publicação: DJe 10/09/2015.

${ }^{19}$ NUCCI, Guilherme de Souza. Crimes contra a dignidade sexual - Comentários da Lei 12.015. São Paulo: Revista dos Tribunais, 2009. p. 37.
} 
que a revogação do art. 224 do CP de 1940, o qual previa expressamente a presunção de violência para os crimes contra os costumes praticados em face de menor de quatorze anos, bem como o surgimento de tipos penais inéditos decorrentes da reforma de 2009, não cessa o debate acerca do caráter relativo ou absoluto da anterior presunção de violência.

Nesse diapasão, os autores alegam que, a despeito do mérito da iniciativa sob outros aspectos, a redação conferida aos novos dispositivos acrescentados pela Lei $\mathrm{n}^{\mathbf{o}}$. 12.015/2009, no que tange aos crimes sexuais contra vulneráveis, representaria empreitada legislativa voltada a deter a orientação que vinha se firmando, à época, na Suprema Corte, no sentido da relatividade da presunção de violência prevista no dispositivo cassado (art. 224) ante a evolução comportamental dos costumes sexuais modernos.

Arquétipo de tal jurisprudência pode ser observado a partir de memorável voto proferido pelo Ministro Marco Aurélio de Mello, o qual, no julgamento de remédio heroico de sua relatoria, discorreu quanto ao antigo art. 224, apregoando que:

A presunção não é absoluta, cedendo às peculiaridades do caso como são as já apontadas, ou seja, o fato de a vítima aparentar mais idade, levar vida dissoluta, saindo altas horas da noite e mantendo relações sexuais com outros rapazes, como reconhecido em seu depoimento.

Nos nossos dias não há crianças, mas moças com doze anos. Precocemente amadurecidas, a maioria delas já conta com discernimento bastante para reagir ante eventuais adversidades, ainda que não possuam escala de valores definidos a ponto de vislumbrar em toda a sorte de consequências que lhes pode advir.

A presunção de violência prevista no art. 224 do Código Penal cede à realidade. Até porque não há como deixar de reconhecer a modificação de costumes havida, de maneira assustadoramente vertiginosa, nas últimas décadas, mormente na atual quadra. Os meios de comunicação de um modo geral e, particularmente, a televisão, são responsáveis pela divulgação maciça de informações, não as

${ }^{20}$ BITTENCOURT, Cezar Roberto. Tratado de Direito Penal. v. 4, $11^{\text {a }}$ ed., São Paulo: Saraiva, 2017. p. 105. 
selecionando sequer de acordo com medianos e saudáveis critérios que pudessem atender às menores exigências de uma sociedade marcada pela dessemelhança ${ }^{21}$.

A manifestação supra restou vencedora na Turma, resultando em acórdão, aprovado por maioria, que perfilha o entendimento de que a presunção de violência, consubstanciada na vetusta norma, seria relativa, senão vejamos:

COMPETÊNCIA - HABEAS-CORPUS - ATO DE TRIBUNAL DE JUSTIÇA. $\mathrm{Na}$ dicção da ilustrada maioria (seis votos a favor e cinco contra), em relação à qual guardo reservas, compete ao Supremo Tribunal Federal julgar todo e qualquer habeas-corpus impetrado contra ato de tribunal, tenha esse, ou não, qualificação de superior. ESTUPRO - PROVA - DEPOIMENTO DA VÍTIMA. Nos crimes contra os costumes, o depoimento da vítima reveste-se de valia maior, considerado o fato de serem praticados sem a presença de terceiros. ESTUPRO CONFIGURAÇÃO - VIOLÊNCIA PRESUMIDA - IDADE DA VÍTIMA NATUREZA. $\underline{O}$ estupro pressupõe o constrangimento de mulher à conjunção carnal, mediante violência ou grave ameaça - art. 213 do Código Penal. $\underline{\mathbf{A}}$ presunção desta última, por ser a vítima menor de 14 anos, é relativa. Confessada ou demonstrada a aquiescência da mulher e exsurgindo da prova dos autos a aparência, física e mental, de tratar-se de pessoa com idade superior aos 14 anos, impõe-se a conclusão sobre a ausência de configuração do tipo penal. Alcance dos art.s 213 e 224, alínea "a", do Código Penal ${ }^{22}$. (grifo nosso).

Não se pretende, aqui, optar por tese tal ou qual, mas, tão somente, demonstrar que a jurisprudência é volúvel, não constituindo os decretos judiciais axiomas incontestáveis, de modo que compete aos operadores do direito o, sempre salutar, exercício crítico de contrapor teorias divergentes para, assim, sob o prisma do princípio da interpretação conforme a Constituição, diante de variedade de acepções possíveis de dada norma infraconstitucional, optar pela exegese que mantenha maior harmonia com as normas insculpidas na Carta Magna, ainda que não seja a que se extraia mais obviamente da literalidade do texto ${ }^{23}$.

\footnotetext{
${ }^{21}$ STF, Habeas Corpus no. 73.662/MG, SEGUNDA TURMA, Rel. Ministro Marco Aurélio de Mello, Data de julgamento: 21/05/1996, Data de Publicação: DJ 20/09/1996.

${ }^{22}$ Ibid.

23 BARROSO, Luís Roberto. Interpretação e aplicação da Constituição: fundamentos de uma dogmática constitucional transformadora. $6^{\circ}$ ed., São Paulo: Saraiva, 2008. p. 189.
} 


\section{CAPÍTULO 3 - A PROTEÇÃO JURÍDICA À DIGNIDADE SEXUAL DA CRIANÇA E DO ADOLESCENTE}

\subsection{Tipos previstos no Código Penal}

O Decreto-Lei $n^{\circ} .2 .848$, de 7 de dezembro de 1940, contém quatro tipos penais dirigidos à preservação da dignidade sexual da infantojuventude - os quais serão examinados mais adiante no corrente capítulo -, todos incluídos pela Lei $\mathrm{n}^{\circ}$. 12.015/2009, que encetou mudanças à normativa penal há muito vindicadas.

Com despertar da Assembleia Nacional Constituinte para a situação de menoscabo do Poder Público em face da infância e da juventude, acompanhado pela edição de normativa protetiva específica, isto é, o ECA, a legislação penal se tornou, deveras, omissa e incompatível com a nova gama de direitos e garantias conferidos aos impúberes da nação.

Em boa verdade, o Código Penal, naquela ocasião, estava alheio às brisas de inovação, podendo-se argumentar, inclusive, insubordinação à hierarquia normativa, eis que, sendo norma infraconstitucional na espécie, forçoso atender aos preceitos da Carta Magna, cuja soberania é incontestável, "sendo o fundamento supremo de validade da ordem jurídica inteira", conforme já advertido, em 1934, por Kelsen²4.

Por tantas e tais razões, adveio a reforma de 2009, oriunda de proposição legislativa formulada por CPMI (Comissão Parlamentar Mista de Inquérito) acerca da violência e das redes de exploração sexual de crianças e adolescentes, cujo escopo, em parte, era atenuar as patentes incongruências entre o direito posto no Código Penal de 1940 e a Doutrina da Proteção Integral, norma programática consubstanciada no art. 227 da Constituição Federal.

\footnotetext{
${ }^{24}$ KELSEN, Hans. Teoria Pura do Direito. São Paulo: Martins Fontes, 1987. p. 240.
} 
Nessa toada, esclarecedor trazer à colação excerto da Exposição de Motivos da norma reformista, que traduz o que ora se busca ilustrar, senão vejamos:

Sobre a legislação penal reinante pairam concepções características de época de exercício autoritário de poder - a primeira metade dos anos 40 - e de padrão insuficiente de repressão aos crimes sexuais, seja por estigmas sociais, seja pelos valores preconceituosos atribuídos ao objeto e às finalidades da proteção pretendida. Trata-se de reivindicação antiga dos grupos e entidades que lidam com a temática, sob o argumento de que a norma penal, além de desatualizada quanto a termos e enfoques, não atende a situações reais de violação da liberdade sexual do indivíduo e do desenvolvimento de sua sexualidade, em especial quando tais crimes são dirigidos contra crianças e adolescentes, resultando, nesse caso, no descumprimento do mandamento constitucional contido no art. $227, \S 4^{\circ}$, de que "a lei punirá severamente o abuso, a violência e a exploração sexual da criança e do adolescente" 25 .

Desse modo, para atender ao mandamento constitucional acima transcrito, a primeira alteração efetuada foi modificar o enunciado do Título VI, que, outrora denominado "Dos Crimes Contra os Costumes", passou a intitular-se "Dos Crimes Contra a Dignidade Sexual".

Importante destacar a relevância que nomenclaturas assumem na seara penal, eis que as alcunhas delimitam o bem-jurídico a ser tutelado. Daí a importância de tal substituição como meio de converter o foco da proteção legal, tendo em vista que a redação antiga era voltada à tutela de hábitos e moralismos - posição arcaica e em completa dissonância com a sociedade hodierna -, ao passo que a concepção alvitrada se disporia a preservar a liberdade e dignidade sexual, bem como o desenvolvimento hígido e salutar da sexualidade.

Além do rebatismo, houve a introdução de capítulo próprio para cuidar do tema, tendo o enunciado do Capítulo II, inserido no Título VI, sido alterado para "Dos Crimes Contra o Desenvolvimento Sexual de

\footnotetext{
${ }^{25}$ BRASIL. Congresso Nacional. Câmara dos Deputados. Exposição de Motivos da Câmara dos Deputados em relação à Lei 12.015/2009, 2004. Disponível em: <http://www2.camara.leg.br/legin/fed/lei/2009/lei-12015-7-agosto-2009-590268exposicaodemotivos-149280-pl.html>. Acesso em: 30 mar. 2018.
} 
Vulnerável", cujo bem-jurídico tutelado já foi abordado no capítulo pretérito.

Tal item passou, portanto, a abarcar tipos penais específicos de proteção àqueles, a saber, estupro de vulnerável (art. 217-A), mediação para servir à lascívia de outrem (art. 218), satisfação de lascívia mediante presença de criança ou adolescente (art. 218-A) e favorecimento da prostituição ou outra forma de exploração sexual de vulnerável (art. 218-B), cujos pormenores serão analisados abaixo.

\subsubsection{Estupro de vulnerável}

Art. 217-A. Ter conjunção carnal ou praticar outro ato libidinoso com menor de 14 (catorze) anos:

Pena - reclusão, de 8 (oito) a 15 (quinze) anos.

§1을 Incorre na mesma pena quem pratica as ações descritas no caput com alguém que, por enfermidade ou deficiência mental, não tem o necessário discernimento para a prática do ato, ou que, por qualquer outra causa, não pode oferecer resistência.

$\S 2^{\circ}$ (Vetado.)

$\S^{\circ}$ Se da conduta resulta lesão corporal de natureza grave:

Pena - reclusão, de 10 (dez) a 20 (vinte) anos

$\S 4$ - Se da conduta resulta morte:

Pena - reclusão, de 12 (doze) a 30 (trinta) anos.

Ao tratar do crime de estupro de vulnerável, assim como dos demais a serem comentados, despiciendo discorrer acerca do bem-jurídico tutelado pelas referidas normas repressivas penais, haja vista a existência de item precedente e específico, inserido no Capítulo 2, destinado a tal fim. 
Dessa forma, superadas tais considerações preliminares, que configuram antecedente lógico e necessário a qualquer análise crítica dos artigos legais, cabe iniciar o escólio pelo exame da polaridade ativa e passiva.

A simples leitura do tipo ilustra que não há qualquer condição especial no que tange ao sujeito ativo, podendo esse ser qualquer pessoa e, inclusive, de ambos os sexos.

Entretanto, eventual circunstância pessoal do autor em relação à vítima representará causa de aumento de pena, nos moldes do art. 226, inciso II, do CP, o qual dispõe que a pena será aumentada de metade "se o agente é ascendente, padrasto ou madrasta, tio, irmão, cônjuge, companheiro, tutor, curador, preceptor ou empregador da vítima ou por qualquer outro título tem autoridade sobre ela", ou seja, se por qualquer forma assumiu obrigação de cuidado, proteção ou vigilância sobre a mesma. Ademais, a norma em questão assenta que o concurso de pessoas também implicará o incremento da sanção, de quarta parte (art. 226, inciso I).

Importante destacar que as indigitadas previsões constituem disposições gerais, de modo que, se o caso for, aplicar-se-ão às infrações a serem examinadas subsequentemente.

Por outro lado, o polo passivo dos delitos previstos no Capítulo II, do Título VI, como a própria nomenclatura da seção vocifera, devem ser praticados contra vulneráveis, cujo conceito fora delineado no tópico 2.2 .

Em outras palavras, indispensável que o sujeito passivo apresente a qualidade de vulnerabilidade imposta pelo legislador, sendo exigido que a vítima não tenha o necessário discernimento para a prática do ato, ou que, por qualquer outra causa, não possa oferecer resistência.

A carência de capacidade de circunspeção é presumida nas hipóteses de menoridade de quatorze anos e de acometimento por enfermidade ou 
doença mental, não guardando, entretanto, as duas últimas circunstâncias, relação com o tema deste ensaio.

Cumpre rememorar, embora ressaltado de antemão em capítulo próprio, que a jurisprudência majoritária entende que a vulnerabilidade do menor de quatorze anos é atingida por presunção absoluta, portanto, sendo desnecessário avaliar ou valorar se a fragilidade é efetiva, não obstante críticas substanciais formuladas por doutrinadores de nomeada, já reproduzidas no item 2.5 .

Por um lado, a adequação típica, no viés objetivo, requer a prática de conjunção carnal ou outros atos libidinosos com vulnerável, logo, se tratando de crime comissivo, pois requer uma ação, e plurissubsistente, já que a conduta pode se desdobrar em vários atos.

Ressalte-se ser desnecessário, para a caraterização do delito, o emprego de violência ou de grave ameaça, meios, contudo, imprescindíveis à configuração do crime de estupro comum (art. 213).

A não exigência da agressividade decorre do fato de que o tipo prescinde da demonstração de dissenso ou de resistência por parte da vítima, haja vista que os menores de quatorze anos não têm capacidade para consentir validamente.

Desse modo, a eventual anuência do vulnerável é juridicamente inexistente, sendo incapaz de afastar a ilicitude da conduta, salvo em circunstâncias excepcionais, tal como a considerada pelo Relator do REsp 1.480.881/PI, que destacou a hipótese de namorados "que mantêm, desde a infância e adolescência de ambos, relacionamento amoroso, resultando em convivência estável após o rapaz completar 18 anos - em que, a depender das peculiaridades do caso, o direito penal não encontra solução proporcional" ${ }^{\prime 26}$.

\footnotetext{
${ }^{26}$ STJ, Recurso Especial (repetitivo), nº. 1.480.881/PI, Terceira Seção, Rel. Ministro Rogério Schietti, julgamento em: 27/08/2015, Data de Publicação: DJe 10/09/2015.
} 
A existência de violência será relevante, entretanto, em duas hipóteses: para afastar a atipicidade decorrente do erro de tipo ou para qualificar o crime.

Quanto ao primeiro ponto, frise-se que, caso o agente, ainda que incurso em erro quanto à idade da vítima, se utilize de violência ou grave ameaça para consumar o fato, a conduta será típica, recebendo o enquadramento do art. 213 do CP, o qual prescinde da condição de vulnerabilidade.

Em relação à qualificação resultante da violência, faz-se mister destacar os parágrafos do art. 217-A, os quais dispõe que: se da conduta resulta lesão corporal de natureza grave ${ }^{27}$, a pena será de 10 (dez) a 20 (vinte) anos $\left(\$ 3^{\circ}\right)$; se da conduta resulta morte, a reclusão é de 12 (doze) a 30 (trinta) anos $\left(\$ 4^{\circ}\right)$.

O legislador almejou, no ponto, exasperar a punibilidade em razão do maior desvalor do resultado, cominando, inclusive, às formas qualificadas, penas que podem superar àquelas que adviriam do concurso crimes entre o delito de natureza sexual e o resultante da violência.

A gravidade das sanções cominadas ao estupro de vulnerável qualificado leva à interpretação de que se teria fugido à regra dos crimes preterdolosos - em que há sempre culpa no consequente -, passando-se a admitir a possibilidade de os resultados agravadores decorrerem de dolo, exegese que se justifica na medida em que evita incongruências legais.

Nessa esteira, uma intepretação sistemática da legislação recomenda que, mesmo havendo dolo direto do agente em relação ao resultado mais gravoso, não se aplique o concurso de crimes dolosos, já que a soma das penas poderá resultar menor do que as cominadas às figuras qualificadas.

Noutro giro, cumpre distinguir o conceito de conjunção carnal da noção de atos libidinosos diversos, haja vista que o primeiro vocábulo

\footnotetext{
${ }^{27} \mathrm{O}$ conceito de lesão corporal de natureza grave pode ser extraído dos $\S 1^{\circ}$ e $\S 2^{\circ}$ do art. 129 do
} $\mathrm{CP}$. 
corresponde ao coito vaginal, ao passo que o último engloba todo ato carnal que, sendo motivado pela volúpia, é capaz de gerar a excitação da libido e o prazer sexual.

Ante a definição exposta, resta claro que a conjunção carnal está abarcada pela concepção de ato libidinoso, entretanto, esse termo também alcança outras práticas lascivas, tal como a cópula anal, o lesbianismo, as inúmeras formas de sexo oral, a masturbação, o coito inter femura, os contatos voluptuosos, etc.

Em breve digressão, cumpre assinalar que, tendo em conta o princípio da proporcionalidade, é possível desclassificar o crime de estupro de vulnerável para a contravenção penal de importunação ofensiva ao pudor, disposta no art. 61 do Decreto-Lei $n^{\circ}$. 3688/1941, o qual tipifica a conduta de "importunar alguém, em lugar público ou acessível ao público, de modo ofensivo ao pudor".

Nada obstante, confrontar as infrações penais supracitadas constitui tarefa árdua, eis que a violência e a grave ameaça não configuram requisitos de nenhuma das espécies. Os parâmetros de distinção são, portanto, parcos, de modo que a orientação do sujeito ativo consiste no principal elemento diferenciador, já que o estuprador é movido pela satisfação da lascívia, enquanto o importunador visa apenas inquietar a vítima, logo, quão mais invasivos forem os atos praticados, mais a conduta se distanciará da LCP.

Ademais, pela própria redação do tipo, a contravenção cotejada requer que a ação aconteça em local público ou acessível ao mesmo, ao passo que o lugar do delito é irrelevante para o crime em comento.

Percebe-se, portanto, que inexistem balizas ou demarcações nítidas entre as transgressões em espeque, de modo que pode haver situações fronteiriças, ambíguas, que sempre representarão penumbras do Direito, e cujas definições jurídicas decorrerão de juízo de valor a ser empregado pelo operador da Lei que esteja em contato direto com o fato. 
Por sua vez, a adequação típica subjetiva do crime de estupro de vulnerável perpassa os componentes integrantes do dolo, a saber, o seu elemento intelectual (consciência) e o seu elemento volitivo (vontade), sem os quais não se poderá falar em crime.

Nessa esteira, para que o dolo se aperfeiçoe, o sujeito ativo deve ter, no momento em que pratica a relação sexual, pleno conhecimento de que se trata de menor de quatorze anos, bem como possuir vontade de incidir naquela conduta.

Assim sendo, não estando presentes, simultaneamente, a consciência e vontade acerca de todas as elementares do tipo penal, o processo intelectual-volitivo não se ultimará, havendo, portanto, a ocorrência de erro de tipo, hipótese em que inexistirá tipicidade, ante a ausência de modalidade culposa correspondente.

Verdadeira zona gris no que tange aos crimes sexuais diz respeito ao dolo eventual, que, no caso, abarcaria hipóteses em que o agente, possuindo incerteza quando à idade da vítima, opta por agir e assume o risco da produção do resultado decorrente de sua conduta.

Coordenador dos trabalhos do Código Penal de 1940 e seu mais abalizado intérprete, Nélson Hungria, ao lecionar quanto ao dolo eventual, pontificou que assumir o risco é alguma coisa mais do que ter consciência de correr o risco: é consentir previamente no resultado, caso este venha efetivamente a ocorrer ${ }^{28}$.

Dessa forma, observa-se que os elementos constitutivos do dolo direto - consciência e vontade -, também são inerentes à variante indireta, sendo, portanto, insuficiente para a sua configuração a mera ciência da

\footnotetext{
${ }^{28}$ HUNGRIA, Nelson. Comentários ao Código Penal. cit., v. 1, t. 2. Rio de Janeiro: Forense,
} 1949. p. 122. 
probabilidade do resultado, já que "a simples previsão da possibilidade de um resultado gravoso é característica da culpa e não do dolo"29.

Em síntese, o dolo direto corresponderia à vontade em razão do resultado, ao passo que o dolo eventual seria a vontade apesar do resultado, havendo, em ambos os gêneros, o consentimento do agente para com o produto, seja por querê-lo, seja por assumir o risco de produzi-lo. Isto é, seja qual for a espécie de dolo, imperioso que haja relação de vontade entre o resultado e o agente, pois é exatamente o elemento volitivo que distingue o dolo da culpa.

O confronto entre dolo eventual e culpa consciente é de extrema importância, tendo em conta que as consequências jurídicas advindas dos elementos subjetivos em realce são diametralmente opostas.

Isto porque nosso Código Penal equipara o dolo eventual ao direto quanto aos seus efeitos, tendo o legislador de 1940 atribuído o mesmo peso às figuras ao adotar a teoria do consentimento, segundo a qual o dolo é a vontade dirigida ao resultado.

Nesse exato sentido, permita-se trazer à colação, in verbis, os termos da Exposição de Motivos do Código Penal de 1940, da lavra do Ministro da Justiça à época, Francisco Campos:

O dolo eventual é, assim, plenamente equiparado ao dolo direto. É inegável que arriscar-se conscientemente a produzir um evento vale tanto quanto querê-lo: ainda que sem interesse nele, o agente o ratifica ex ante, presta anuência ao seu $\operatorname{advento}^{30}$.

Logo, a aquiescência do autor do fato para com os frutos de sua conduta constitui fator decisivo no cotejo entre dolo eventual e culpa consciente, tendo em vista que nesta o agente não quer resultado nem assume deliberadamente o risco de produzi-lo, agindo porque confia convictamente que ele não ocorrerá.

\footnotetext{
${ }^{29}$ BITTENCOURT, Cezar Roberto. Tratado de Direito Penal. v. 1, $22^{\mathrm{a}}$ ed., São Paulo: Saraiva, 2016. p. 364.

${ }^{30}$ Ibid., p. 365.
} 
O paralelo ora proposto traduz-se em ponto nevrálgico em relação aos delitos que não tipificam a culpa, o que se verifica na espécie, de modo que, a depender da definição atribuída ao ânimo do agente que pratica o injusto sexual, haverá tipicidade ou não.

Nesse sentido, sendo deliberado que o agente agiu com dolo eventual, ele estará incurso nas mesmas sanções aplicáveis àquele que atuou com dolo direto, a saber, de 8 (oito) a 15 (quinze) anos de reclusão. Diversamente, em tendo havido culpa, o sujeito estará abarcado pelo instituto do erro de tipo, não respondendo penalmente diante da inexistência de previsão de coima a título de culposo, sendo, portanto, sua conduta inteiramente atípica. Daí a magnitude do contraste de tais conceitos jurídicos.

A aplicação prática de tal conteúdo é extremamente complicada, já que a constatação do dolo eventual é de difícil comprovação, mormente porque a análise do animus depende da aferição do complexo processo psicológico do agente, que se dá em seu impenetrável âmago.

Em suma, a visão garantista adverte que, pairando dúvida entre a ocorrência de dolo eventual ou culpa consciente, sob a luz dos princípios do in dubio pro reo e da presunção de inocência, ambos de estatura constitucional, caberá optar pela última e menos gravosa.

Por derradeiro, o estupro se trata de crime material, eis que o mesmo causa transformação no mundo exterior, deixando vestígios, de modo que só se consuma com a efetiva produção do resultado naturalístico descrito no tipo (conjunção carnal ou outro ato libidinoso). Exatamente por ser material, é que o crime admite a tentativa, a despeito da dificuldade prática de sua constatação, a qual é caracterizada quando, uma vez iniciada a execução, o agente é interrompido pela reação eficaz da vítima ou pela intervenção de terceiro.

Um dos potenciais rastros deixados pelo estupro é a gravidez. 
A gestação decorrente de violência sexual constitui uma das hipóteses de abortamento legal, conforme preconiza o art. 128, inciso II, do $\mathrm{CP}$, ao dispor que o aborto não é punível "se a gravidez resulta de estupro e o aborto é precedido de consentimento da gestante ou, quando incapaz, de seu representante legal".

Conforme se extrai da redação da própria norma, a efetivação do procedimento prescinde do trânsito em julgado de sentença condenatória (por questões óbvias, tendo em vista a morosidade da Justiça), bem como da existência de acusação formal em face do ofensor, bastando a autorização escrita da vítima, ou, quando essa for incapaz, de seu tutor.

A suficiência do aval da mulher é reconhecida, inclusive, na Norma Técnica do Ministério da Saúde sobre Prevenção e Tratamento dos Agravos Resultantes da Violência Sexual contra Mulheres e Adolescentes, tendo em vista que o Diploma, à fl. 71, assegura que:

A realização do abortamento não se condiciona à decisão judicial que sentencie e decida se ocorreu estupro ou violência sexual. A lei penal brasileira também não exige alvará ou autorização judicial para a realização do abortamento em casos de gravidez decorrente de violência sexual. $\mathrm{O}$ mesmo cabe para o Boletim de Ocorrência Policial e para o laudo do Exame de Corpo de Delito e Conjunção Carnal, do Instituo Médico Legal. Embora esses documentos possam ser desejáveis em algumas circunstâncias, a realização do abortamento não está condicionada a apresentação dos mesmos. Não há sustentação legal para que os serviços de saúde neguem o procedimento caso a mulher não possa apresentá$\operatorname{los}^{31}$.

\subsubsection{Uso de menor para satisfazer a lascívia de outrem}

Art. 218. Induzir alguém menor de 14 (catorze) anos a satisfazer a lascívia de outrem:

Pena - reclusão, de 2 (dois) a 5 (cinco) anos.

Parágrafo único. (Vetado.)

\footnotetext{
${ }^{31}$ Disponível em:

<http://bvsms.saude.gov.br/bvs/publicacoes/prevencao_agravo_violencia_sexual_mulheres_3ed.p df>. Acesso em: 05 mai. 2018.
} 
O dispositivo em comento tipifica a ação de induzir alguém, menor de 14 (quatorze) anos, ou seja, tomar a iniciativa intelectual de suscitar uma ideia até então não existente na mente da vítima, com a finalidade específica de levá-la a satisfazer a lascívia de outrem.

Vale realçar, no ponto, as lições Nelson Hungria, o qual, ao tratar do induzimento, professou que o mesmo consistia:

No emprego de suasões, promessas, engodos, dádivas, súplicas, propostas reiteradas, numa palavra: todo expediente (não violento ou fraudulento) que tenha sido idôneo ou eficiente para levar a vítima a satisfazer a lascívia de outrem ${ }^{32}$.

Para os fins do art. 218, a satisfação da lascívia deve se dar por meios outros que não a prática de conjunção carnal ou outro ato libidinoso, caso contrário haverá a incidência do crime de estupro de vulnerável, a abarcar tanto o aliciante quanto o beneficiário da sedução.

Nesse sentido, o tipo penal em apreço marginaliza o contentamento da libido através de práticas sexuais contemplativas e exibicionistas, dispensando a presença de contato físico entre o menor e o terceiro. Não é outro o entendimento esposado por Rogério Greco, senão vejamos:

Por satisfazer a lascívia somente podemos entender aquele comportamento que não imponha à vítima, menor de 14 (catorze) anos, a prática de conjunção carnal ou outro ato libidinoso, uma vez que, nesses casos, teria o agente que responder pelo delito de estupro de vulnerável, em virtude da regra constante do art. 29 do Código Penal, que seria aplicada ao art. 217-A do mesmo diploma repressivo ${ }^{33}$.

Quanto aos sujeitos do delito, é possível que haja, na polaridade ativa, a presença de qualquer pessoa, independente de sexo ou condição especial, eis que eventual relação especial do agente em relação à vítima, tal qual o parentesco, apenas majora o crime.

No que tange ao sujeito passivo, imprescindível cuidar-se de menor de 14 (quatorze) anos. Isso porque, em se tratando de pessoa adulta, isto é,

\footnotetext{
${ }^{32}$ HUNGRIA, Nelson. Comentários ao Código Penal. $5^{\text {a }}$ ed., v. VIII. Rio de Janeiro: Forense, 1981. p. 259.

${ }^{33}$ GRECO, Rogério. Código Penal Comentado. $4^{\text {a }}$ ed., Niterói: Impetus, 2010. p. 622-623.
} 
maior de 18 (dezoito anos), a capitulação invocará o art. 227, ou, na hipótese da faixa etária da vítima corresponder ao interregno entre as idades supracitadas, aplicar-se-á a forma qualificada prevista no $\S 1^{\circ}$ da norma última.

Curioso destacar que, embora o crime de "uso de menor para satisfazer a lascívia de outrem" exija, imperiosamente, a participação de outrem, o qual é referido na própria redação do tipo, tal terceiro não é coautor do delito, tampouco é punido. Em outras palavras, tipifica-se a conduta do mediador, mas não a de quem efetivamente se beneficia da conduta do vulnerável por meio, ressalte-se, de contemplação lúbrica somente, sob pena de se adentrar em mares mais profundos de tipicidade.

Em relação à adequação típica subjetiva, ressalte-se que o dolo deve consistir na vontade consciente de induzir a vítima a praticar ação voltada a satisfazer a lascívia de outrem, bem como deve englobar a situação de vulnerabilidade.

Nos moldes já expostos acima, o art. 227 se aplicará nos casos em que o agente não tinha, quando da prática do delito, consciência de que se tratava de menor de 14 (quatorze) anos.

A consumação do crime formal exposto ocorre com o induzimento da vítima, isto é, quando o agente efetivamente convence o menor a satisfazer a luxúria de terceiro, sendo a eventual exultação ou não da lascívia alheia desimportante para fins consumativos, eis que representa mero exaurimento do crime. A esfera da tentativa se restringe, portanto, às hipóteses em que o menor, embora induzido por seu algoz, não venha a praticar o ato por motivos estranhos à vontade do aliciador.

A redação do tipo demonstra que o legislador optou pela antecipação da consumação do crime, objetivando conferir maior proteção àqueles que não possuem aptidão volitiva do ponto de vista sexual. 


\subsubsection{Satisfação de lascívia mediante presença de criança ou adolescente}

Art. 218-A. Praticar, na presença de alguém menor de 14 (catorze) anos, ou induzi-lo a presenciar, conjunção carnal ou outro ato libidinoso, a fim de satisfazer lascívia própria ou de outrem:

Pena - reclusão, de 2 (dois) a 4 (quatro) anos.

A norma em enfoque foi antecedida pelo art. 218 do CP, o qual continha o crime de corrupção de menores, que tipificava a conduta de “corromper ou facilitar a corrupção de pessoa maior de 14 (quatorze) e menor de 18 (dezoito) anos, com ela praticando ato de libidinagem, ou induzindo-a a praticá-lo ou presenciá-lo".

Latente, ante o excerto acima, a lacuna existente, à época, no ordenamento jurídico, eis que o vetusto tipo penal não alcançava os menores de 14 (anos). Nessa toada, permita-se trazer à colação o magistério de Rogério Sanches, ao pontuar que "a doutrina, não sem razão, observava que induzir a vítima, não maior de 14 anos, a presenciar atos de libidinagem, sem deles participar ativa ou passivamente, era, em regra, um indiferente penal (fato era atípico)" ${ }^{\text {34 }}$. Logo, a introdução do presente art., promovida pela Lei 12.015/2009, almejou, exatamente, preencher o vácuo normativo assinalado, de modo a evitar o estímulo precoce da sexualidade.

Na linha do que já foi exposto ao tratar dos crimes abordados supra, o sujeito ativo do delito pode ser qualquer pessoa, haja vista se tratar de crime comum, ao passo que o sujeito passivo deve, impreterivelmente, ser pessoa menor de 14 (quatorze) anos.

Objetivamente, o tipo abarca condutas alternativas, havendo, por um lado, a prática de conjunção carnal ou outro ato libidinoso na presença da vítima, e, por outro, a indução da vítima a presenciar tais fatos.

\footnotetext{
${ }^{34}$ CUNHA, Rogério Sanches. Comentários à reforma criminal de 2009. São Paulo: Revista dos Tribunais, 2009. p. 55.
} 
Na primeira circunstância, o agente, desrespeitando a presença do vulnerável, pratica atos carnais para satisfazer a lascívia própria ou de terceiro, não havendo, assim, qualquer ingerência na manifestação de vontade da vítima, servindo-se de sua presença para o deleito da volúpia. Nesse caso, a consumação se dará com a efetiva prática, na presença do imberbe, de ato libidinoso.

Na segunda conjectura, há interferência direta na autodeterminação da vítima - ainda incapaz de originar volição hígida -, eis que o induzimento do autor faz germinar na mente do vulnerável o intuito de presenciar a libidinagem, assim, maculando a sua vontade. A consumação dessa modalidade resultará da obtenção do assentimento da vítima em assistir ao ato lascivo.

Em ambas as modalidades citadas a consumação prescinde da efetiva satisfação da lascívia, cuja ocorrência apenas significará o exaurimento do crime, tendo em vista se tratar de elemento subjetivo especial do injusto, que pauta a conduta do sujeito ativo. Doutrinariamente, o art. 218-A admite a forma tentada, muito embora seja difícil placitar a sua constatação.

Em nenhuma hipótese haverá contato físico sensual entre o autor do fato e a vítima, sendo a participação da mesma limitada à observação, caso contrário haverá transmutação da tipificação, ou seja, se o menor participar diretamente dos atos lascivos, a conduta corresponderá ao crime do art. 217-A.

Ainda quanto à adequação objetiva do tipo, cumpre trazer à baila o embate travado entre alguns doutrinadores em relação ao significado de "presença", isto é, há quem argumente, valendo citar Bittencourt, que o vulnerável deve se encontrar fisicamente no local onde se realiza a cena concupiscente, de modo a assisti-la "in loco, e não indiretamente, via 
qualquer mecanismo tecnológico, físico ou virtual, como permitiria o mundo tecnológico"35.

Nada obstante, os paladinos da possibilidade de a interação do menor ser não presencial, dentro os quais Nucci, aduzem que:

A evolução tecnológica já propicia a presença - estar em determinado lugar ao mesmo tempo em que algo ocorre - por meio dos aparelhos apropriados. Portanto, o menor pode a tudo assistir ou presenciar por meio de câmaras e aparelhos de TV ou monitores. A situação é válida para a configuração do tipo penal, uma vez que não se exige qualquer toque físico em relação à vítima ${ }^{36}$.

Talvez o último posicionamento se enquadre melhor aos tempos atuais, tendo em vista os meios de comunicação existentes, todavia, cumpre assinalar, também, que o Direito Penal da culpabilidade não admite a elasticidade interpretativa, não se podendo, ao arrepio do princípio da tipicidade estrita, tipificar conduta não abarcada pela norma incriminadora.

Passando a tratar da tipicidade subjetiva, certo é que o dolo do agente consiste na satisfação da lascívia própria ou de outrem mediante a presença de vulnerável, dessa forma, o prazer sexual do agente reside, fundamentalmente, em saber que um menor está assistindo à execução do ato libidinoso, e não na atividade sexual em si.

\subsubsection{Favorecimento da prostituição ou outra forma de exploração sexual de criança ou adolescente ou de vulnerável}

Art. 218-B. Submeter, induzir ou atrair à prostituição ou outra forma de exploração sexual alguém menor de 18 (dezoito) anos ou que, por enfermidade ou deficiência mental, não tem o necessário discernimento para a prática do ato, facilitá-la, impedir ou dificultar que a abandone:

Pena - reclusão, de 4 (quatro) a 10 (dez) anos.

§1을 Se o crime é praticado com o fim de obter vantagem econômica, aplica-se também multa.

${ }^{35}$ BITTENCOURT, 2017, p. 133.

${ }^{36}$ NUCCI, 2009, p. 50. 
$\S 2^{\circ}$ Incorre nas mesmas penas:

I - quem pratica conjunção carnal ou outro ato libidinoso com alguém menor de 18 (dezoito) e maior de 14 (catorze) anos na situação descrita no caput deste art.;

II - o proprietário, o gerente ou o responsável pelo local em que se verifiquem as práticas referidas no caput deste art.

$\S 3^{\circ} \mathrm{Na}$ hipótese do inciso II do $2^{\circ}$, constitui efeito obrigatório da condenação a cassação da licença de localização e de funcionamento do estabelecimento.

O último tipo, insculpido na Lei Penal, voltado à proteção da formação moral sexual dos menores está disposto no art. 218-B, o qual criminaliza atos diversos atinentes à exploração sexual de vulnerável.

A inserção de tal crime, promovida pela reforma de 2009, acarretou a revogação tácita do art. 244-A do ECA, eis que todo o seu conteúdo foi reproduzido pela norma em espeque, a qual prevalece sob a égide do critério cronológico, ou seja, por ser lei mais recente.

Importante destacar as mudanças inauguradas pela Lei 12.978/2014, já que a mesma ocasionou duas alterações no ordenamento jurídico, ambas relacionadas ao crime que ora se comenta.

Primeiramente, a parca técnica legislativa utilizada em sua formulação provocou incoerência entre o nomen iuris do delito e o seu conteúdo descritivo, eis que a norma modificadora alterou a denominação do tipo, incluindo ao seu texto a locução "criança e adolescente", sem, contudo, promover a correlata permuta na redação do $\S 2^{\circ}$, inciso I, do tipo penal incriminador, o qual faz referência a "menor de 18 (dezoito) e maior de 14 (quatorze) anos". Ou seja, ao introduzir o vocábulo "criança" sem alterar a definição do crime, ignorou-se que o inciso I da norma somente abarca os maiores de 14 (quatorze) anos e que não há crianças nessa faixa etária.

Segundamente, o Congresso Nacional, a guisa da legislação alhures, transformou o crime em referência em hediondo, passando o tipo a figurar 
no inciso VII do rol do art. $1^{\circ}$ da Lei 8.072/1990, sendo, por conseguinte, insuscetível de anistia, graça, indulto ou fiança, bem como sujeitando o seu autor a uma disciplina diferenciada de progressão de regime e de prisão temporária, conforme consta do art. $2^{\circ}$ da Lei de Crimes Hediondos.

Feitas tais considerações, cumpre iniciar a glosa abordando os sujeitos do tipo, haja vista que a norma em comento possui particularidades em relação aos três crimes acima ilustrados, muito embora não haja nada de novel a destacar quanto à polaridade ativa, que pode ser ocupada por qualquer pessoa, não havendo exigência de qualidade ou condição especial. Nessa esteira, as especificidades tangem o polo passivo, que deve ser ocupado por menor de 18 (dezoito) e maior de 14 (quatorze) anos, estando a novidade exatamente no intervalo etático, tendo em conta que a redação dos art.s 217-A, 218 e 218-A faz alusão expressa ao "menor de 14 (quatorze) anos".

Tal inovação na polaridade passiva não foi acompanhada de justificativa legislativa, decorrendo de mera opção político-criminal, de modo que a adjetivação de vulnerável para tal faixa etária díspar leva à interpretação de que se estaria tratando de espécie distinta de vulnerabilidade, a saber, a relativa.

A vulnerabilidade relativa, ao contrário da absoluta, não é presumida, tendo em conta que a mesma incide somente caso haja comprovação da efetiva condição de vulnerável, o que deve se aferido casuisticamente, através da indicação de circunstâncias fáticas, pessoais, emocionais e jurídicas que demonstrem o estado de fragilidade, sob pena de atipicidade da conduta.

Não se desconhece que estão incluídos dentre as vítimas em potencial os enfermos ou doentes mentais que não possuam discernimento para a prática do ato, entretanto, tal condição peculiar de vulnerabilidade não corresponde ao cerne deste esboço, de modo que não serão traçadas maiores ponderações quanto ao tema. 
A adequação objetiva do tipo perpassa os conceitos de prostituição e exploração sexual, ambos caracterizados pelo exercício habitual da promiscuidade em face de número indeterminado de pessoas, e diferenciados pelo fato de que ao se prostituir a vítima ganha algum bem em troca, ao passo que ao ser explorada ela não recebe nada.

Cuida-se de tipo misto alternativo, sendo diversas as condutas incriminadas, as quais são fungíveis entre si, de modo que a incursão em mais de um dos verbos nucleares, no mesmo contexto fático, resultará na prática de um único crime. Imprescindível que tais condutas sejam dotadas de habitualidade, tendo em vista que o tipo constitui-se de atos que, considerados isoladamente, são irrelevantes penais.

As primeiras quatro condutas dispostas - submeter, induzir, atrair e facilitar -, representam formas de aliciamento da volição da vítima, a qual é seduzida para a finalidade em espeque. Submeter significa sujeitar, subjugar, impor; induzir é tomar a iniciativa intelectual de suscitar na mente de outrem uma ideia até então inexistente; atrair corresponde à atividade de estimular e cativar o vulnerável; sendo que nessas três hipóteses a vítima ainda não estava inserida no contexto de meretrício.

No sentido oposto, os vocábulos facilitar, impedir e dificultar abrangem sujeito passivo já mantido no quadro de prostituição ou de exploração sexual. A facilitação corresponde à criação dos meios indispensáveis à consumação do delito, ou seja, traduz-se no afastamento de empecilhos e no auxílio prestado a vítima, propiciando-lhe os mecanismos inerentes à prática, seja por lhe arranjar clientes, seja por lhe apontar locais adequados para fazê-lo. O facilitamento também pode ocorrer pela omissão daquele que, por ser garantidor, esteja obrigado a impedir a mercantilização carnal.

As últimas duas condutas, impedir ou dificultar, visam evitar que a vítima abandone o contexto de libertinagem, traduzindo-se o primeiro vocábulo no emprego de ameaças, de coação moral, psicológica ou 
econômica, enquanto o último reflete a criação de embaraços e exigências irrazoáveis.

O favorecimento da prostituição de vulnerável não requer, para a sua configuração, a finalidade lucrativa, a qual, caso exista, resultará na aplicação cumulativa de pena de multa, segundo a inteligência do $\S 1^{\circ}$ do art. 218-B.

O tipo, ao revés de como opera o art. $228, \S 2^{\circ}$, não é qualificado pelo emprego de violência, grave ameaça ou fraude, de modo que, caso tais condutas ocorram e constituam crimes em si mesmos, haverá concurso de crimes com o delito correspondente.

Merece ênfase o fato de o tipo equiparar algumas condutas às do caput, determinando, nos termos do $\$ 2^{\circ}$ da norma, que incorre na mesma pena:

I - quem pratica conjunção carnal ou outro ato libidinoso com alguém menor de 18 (dezoito) e maior de 14 (quatorze) anos na situação descrita no caput;

II - o proprietário, o gerente ou o responsável pelo local em que se verifiquem as práticas referidas no caput deste art.

O inciso I abarca a situação dos clientes de menores de 18 (dezoito) e maiores de 14 (quatorze) anos, merecendo destaque que a prática sexual com tal segmento só será típica se inserida "na situação descrita no caput", ou seja, no contexto de prostituição ou exploração sexual, de modo que a relação sexual livre e espontânea praticada com maior de 14 (quatorze) anos permanece penalmente irrelevante.

A previsão em comento causa algumas divergências interpretativas quanto a sua aplicação ou não ao cliente que, ocasionalmente, mantém relação sexual com o menor já prostituído.

Por um lado, argumenta-se que a conduta do cliente eventual não submete o vulnerável à prostituição, pois não o coloca ou o mantém em situação de prostituído, sendo essa uma condição preexistente para a qual o 
agente não concorreu. Segundo essa linha, a conduta do cliente ocasional não se enquadraria na descrição contida no dispositivo em exame, sendo, portanto, atípica.

Sob ótica divergente, há quem postule que a Lei 12.015/2009, ao inovar em relação à norma de regência prévia, art. 244-A, objetivou, exatamente, criminalizar a conduta daquele que mantém relação sexual, ainda que esporádica, com o vulnerável, tendo em vista que a regra anterior não abordava tal sujeito ativo, vigendo com a seguinte redação:

Art. 244-A. Submeter criança ou adolescente, como tais definidos no caput do art. $2^{\circ}$ desta Lei, à prostituição ou à exploração sexual:

Pena - reclusão de quatro a dez anos, e multa.

§1 Incorrem nas mesmas penas o proprietário, o gerente ou o responsável pelo local em que se verifique a submissão de criança ou adolescente às práticas referidas no caput deste art..

§2 Constitui efeito obrigatório da condenação a cassação da licença de localização e de funcionamento do estabelecimento.

Nessa esteira, com escora no preceito basilar de hermenêutica jurídica segundo o qual a lei não contém palavras inúteis ${ }^{37}$ - verba cum effectu sunt accipienda - caberia conferir eficácia normativa à inovação legislativa, sendo, portanto, típica a conduta daquele que mantém contato sexual com o menor prostituído.

Por sua vez, o inciso II, colacionado acima, é alvo de muitas críticas. Isso porque a referida norma não contém verbo nuclear algum que defina a conduta proibida, bem como não descreve qualquer ação humana, limitando-se a atribuir responsabilidade penal ao proprietário ou responsável pelo local, por fatos, praticados por outrem, que ocorram em seu interior, simplesmente em razão de ostentar tal qualidade.

\footnotetext{
37 MAXIMILIANO, Carlos. Hermenêutica e Aplicação do Direito. $8^{\mathrm{a}}$ ed., São Paulo: Freitas Bastos, 1965. p. 262.
} 
Inteiramente diferente seria a incriminação do proprietário, gerente ou responsável pelo local em que se praticam as condutas lascivas, que concorra ativamente para o delito, hipótese em que se aplicaria o caput.

Nessa toada, a ausência de verbo que identifique conduta humana inviabiliza a perquirição quanto à culpa do agente, o que dá azo à responsabilidade penal objetiva, própria dos regimes totalitários.

O moderno Estado Constitucional de Direito, norteado por princípios democráticos, tal como o da responsabilidade penal subjetiva e individual, aderiu ao direito penal do fato e da culpabilidade, de acordo com o qual nullum crimen sine culpa.

Evidente, portanto, que o emprego do dispositivo nesses moldes não pode prosperar em nosso ordenamento jurídico, sob pena de regredirmos ao direito penal do autor.

Dessa forma, o $\S^{\circ}$ só será aplicável caso reste comprovado o dolo do agente, ou seja, a consciência da atividade desempenhada no local e a vontade de não agir para impedi-la, tendo em vista que, nos termos do art. $13, \S 2^{\circ}$, do $\mathrm{CP}$, há relação de causalidade entre o resultado e a omissão sem a qual o mesmo não teria ocorrido, sendo, portanto, penalmente relevante a omissão do proprietário, do gerente ou do responsável pelo local que, ciente das práticas lascivas, não age para coibi-las.

O elemento subjetivo do tipo corresponde ao dolo do agente, que se compõe da vontade consciente de praticar qualquer dos verbos dispostos no tipo em face dos sujeitos passivos elencados, devendo a subjetividade abranger, também, a condição de vulnerabilidade da vítima. Caso o agente desconheça a menoridade da vítima, será possível invocar erro de tipo e, a depender da hipótese, haverá desclassificação para o delito do art. 228.

A consumação do crime de favorecimento da prostituição ou de outra forma de exploração sexual prescinde da efetiva entrega da vítima às 
referidas atividades, conforme aponta Rogério Sanches Cunha, senão vejamos:

\begin{abstract}
Nas modalidades induzir, atrair e facilitar consuma-se o delito no momento em que a vítima passa a se dedicar à prostituição ou outra forma de exploração sexual, colocando-se, de forma constante, à disposição dos clientes, ainda que não tenha atendido nenhum. Já na modalidade de impedir ou dificultar o abandono da prostituição, o crime consuma-se no momento em que a vítima delibera por deixar a atividade e o agente obsta esse intento, protraindo a consumação durante todo o período de embaraço (crime permanente) ${ }^{38}$.
\end{abstract}

Logo, trata-se de crime material, eis que a sua consumação exige, como resultado, que a vítima incorpore o meretrício, assim, almejando adotar, como meio de vida, a prostituição, independente de já ter praticado algum ato carnal. Difícil a constatação do delito em sua modalidade tentada, embora, em tese, admita-se a tentativa.

\title{
3.2 Tipos previstos no Estatuto da Criança e do Adolescente
}

A trincheira de proteção erigida pela Lei 8.069/1990 ao redor da dignidade sexual dos sujeitos que ampara parte de perspectiva diversa daquela adotada pelo CP.

Isso porque a dogmática penal se ateve a moldes tradicionais, prevendo gama de infrações que, nos tempos atuais, podem ser insuficientes na consecução da finalidade precípua dos indigitados tipos penais, qual seja, zelar pela proteção integral dos jovens, em suas múltiplas facetas.

O Estatuto da Criança e do Adolescente, por sua vez, não ignorou as expressivas repercussões da Revolução Digital ocorrida na década de 90, que significou o amplo acesso à internet através do World Wide Web. Os novos meios de comunicação promoveram verdadeira transformação paradigmática, abalando o convívio da comunidade, que agora se tornou global, e afetando o modo como os membros da sociedade se relacionam.

\footnotetext{
38 CUNHA, Rogério Sanches. Direito Penal, Parte Especial. $3^{\mathrm{a}}$ ed., São Paulo: Revista dos Tribunais, 2010. p. 263.
} 
A criminalidade não foi indiferente a isso.

Com o advento das novas tecnologias, a delinquência também evoluiu, passando a se valer de tais veículos para perpetrar ofensas.

A par disso, o ECA prevê preceitos primários para o combate dos crimes cibernéticos, mormente no que tange à preservação da sexualidade dos menores.

Nesse diapasão, a reforma introduzida pela Lei 11.829/2008 foi imprescindível para que a lei de regência acompanhasse os passos da modernidade, seja pela geração de figuras típicas inéditas, seja pelo maior detalhamento das condutas daqueles que se valem da rede mundial de computadores para afligir os impúberes.

Antes de adentrar a análise minuciosa dos referidos delitos, cumpre tecer observações relativas a elemento normativo reproduzido inúmeras vezes ao longo da legislação em comento, a saber, o termo "cena de sexo explícito ou pornográfica".

Os elementos normativos do tipo integram a norma e, para serem aplicados, dependem de atividade interpretativa, isto é, que o aplicador da lei exerça juízo de valor quanto ao significado jurídico e social de determinada expressão empregada pela lei.

No caso em apreço, o conceito da locução, pode ser extraído do próprio diploma legal, eis que o art. 241-E dispõe o quanto segue:

\footnotetext{
Para efeito dos crimes previstos nesta Lei, a expressão "cena de sexo explícito ou pornográfica" compreende qualquer situação que envolva criança ou adolescente em atividades sexuais explícitas, reais ou simuladas, ou exibição dos órgãos genitais de uma criança ou adolescente para fins primordialmente sexuais.
}

Contudo, a jurisprudência já assentou que o significado dos vocábulos não se encerra na definição legal colacionada acima, valendo destacar que a interpretação dos magistrados tem sido no sentido de que a 
cena pornográfica prescinde de contato sexual direto, tampouco requer a expressa exibição dos órgãos genitais.

Logo, sob esse prisma, para a configuração de pornografia infantil, bastaria o registro de atividades sexuais implícitas e de poses inadequadas, sendo desnecessária a nudez. Nesse exato sentido, permita-se colacionar arresto do Superior Tribunal de Justiça:

RECURSO ESPECIAL. PENAL E PROCESSO PENAL. SESSÃO DE JULGAMENTO. PARTICIPAÇÃO DE DESEMBARGADOR QUE NÃO ESTEVE PRESENTE NO INÍCIO DO JULGAMENTO E SE DECLAROU APTO PARA PROFERIR O VOTO. POSSIBILIDADE. LEGITIMIDADE ATIVA DO MINISTÉRIO PÚBLICO. AÇÃO PÚBLICA CONDICIONADA À REPRESENTAÇÃO. AUSÊNCIA DE IMPUGNAÇÃO DE TODOS OS FUNDAMENTOS DO ACÓRDÃO. INCIDÊNCIA DA SÚMULA 283/STF. ATENTADO VIOLENTO AO PUDOR CONTRA CRIANÇA. PALAVRA DA VÍTIMA. ALTO VALOR PROBATÓRIO. REEXAME DE FATOS E PROVAS. IMPOSSIBILIDADE. SÚMULA 7/STJ. CRIME DE FOTOGRAFAR CENA PORNOGRÁFICA ENVOLVENDO CRIANÇA OU ADOLESCENTE (ART. 240 DA LEI N. 8.069/1990). CRIME DE ARMAZENAR FOTOGRAFIAS DE CONTEÚDO PORNOGRÁFICO ENVOLVENDO CRIANÇA OU ADOLESCENTE (ART. 241-B DO ESTATUTO DA CRIANÇA E DO ADOLESCENTE). PORNOGRAFIA INFANTIL. ART. 241-E DO ESTATUTO DA CRIANÇA E DO ADOLESCENTE. DEFINIČÃO INCOMPLETA. TIPOS PENAIS ABERTOS. ENFOQUE NOS ÓRG ̃̃OS GENITAIS, AINDA QUE COBERTOS, E POSES SENSUAIS. SEXUALIDADE EXPLORADA. CONOTAÇÃO OBSCENA E FINALIDADE SEXUAL E LIBIDINOSA. MATERIALIDADE DOS DELITOS.

1. De acordo com entendimento deste Superior Tribunal de Justiça, não há falar em nulidade se o Desembargador que não esteve presente no início do julgamento, quando da sessão de leitura do relatório e sustentação oral, declara sua aptidão para proferir o voto com respaldo em previsão do próprio Regimento Interno do Tribunal local.

2. Em não havendo a impugnação de todos os fundamentos autônomos contidos no acórdão recorrido, considerados suficientes, por si só, para manter o julgado impugnado, tem incidência o óbice da Súmula 283/STF.

3. A jurisprudência deste Superior Tribunal de Justiça há muito se consolidou no sentido de que, em se tratando de crimes contra a liberdade sexual, a palavra da vítima tem alto valor probatório, considerando que delitos dessa natureza geralmente não deixam vestígios $\mathrm{e}$, em regra, tampouco contam com testemunhas. 
4. A reforma do aresto impugnado, que concluiu pela efetiva comprovação da prática de atos libidinosos diversos da conjunção carnal descritos na exordial acusatória, demandaria o necessário reexame de matéria fático-probatória, o que é vedado no julgamento do recurso especial por esta Corte Superior de Justiça, que não pode ser considerada uma terceira instância revisora ou tribunal de apelação reiterada, a teor do enunciado $n^{\circ} 7$ da súmula deste Sodalício.

5. A definição legal de pornografia infantil apresentada pelo artigo 241-E do Estatuto da Criança e do Adolescente não é completa e deve ser interpretada com vistas à proteção da criança e do adolescente em condição peculiar de pessoas em desenvolvimento (art. $6^{\circ}$ do ECA), tratando-se de norma penal explicativa que contribui para a interpretação dos tipos penais abertos criados pela Lei $\mathrm{n}^{\mathrm{o}} 11.829 / 2008$, sem contudo restringir-lhes o alcance.

6. É típica a conduta de fotografar cena pornográfica (art. 241-B do ECA) e de armazenar fotografias de conteúdo pornográfico envolvendo criança ou adolescente (art. 240 do ECA) na hipótese em que restar incontroversa a finalidade sexual e libidinosa das fotografias, com enfoque nos órgãos genitais das vítimas - ainda que cobertos por peças de roupas -, e de poses nitidamente sensuais, em que explorada sua sexualidade com conotação obscena e pornográfica.

7. Recurso especial improvido ${ }^{39}$. (grifos nossos)

A despeito da posição pretoriana ilustrada, cumpre ressalvar que, em matéria de direito penal, o mais aconselhável é a não adoção de interpretações extensivas, tendo em conta que leituras restritivas guardam melhor relação com o princípio da reserva legal.

A questão da legalidade é agravada, exatamente, no que tange a elementos normativos do tipo, cuja aplicação depende intrinsecamente de juízo valorativo, ensejando atividade interpretativa dos operadores do Direito. Assis Toledo acrescenta ao embate na medida em que oferece balizas a nortear a interpretação das leis, alertando que o princípio do in dubio pro reo, bem como o da prevalência dos elementos descritivos sobre os normativos, constituem pontos de referência sólidos a auxiliar a tomada de decisão final sobre a ampliação ou restrição do preceito que se busca

\footnotetext{
${ }^{39}$ STJ, Recurso Especial 1.543.267/SC, SEXTA TURMA, Rel. Ministra Maria Thereza de Assis Moura, Data de julgamento: 03/12/2015, DJe 16/02/2016.
} 
interpretar $^{40}$. Dessa forma, ante o gizado acima, caberia questionar até que ponto o posicionamento do STJ é correto sob uma ótica jurídicoconstitucional.

\title{
3.2.1 Qualquer forma de participação na produção de cena de sexo explícito ou pornográfica envolvendo criança ou adolescente
}

\begin{abstract}
Art. 240. Produzir, reproduzir, dirigir, fotografar, filmar ou registrar, por qualquer meio, cena de sexo explícito ou pornográfica, envolvendo criança ou adolescente:

Pena - reclusão, de 4 (quatro) a 8 (oito) anos, e multa.

$\$ 1^{\circ}$ Incorre nas mesmas penas quem agencia, facilita, recruta, coage, ou de qualquer modo intermedeia a participação de criança ou adolescente nas cenas referidas no caput deste art., ou ainda quem com esses contracena.
\end{abstract}

$\S 2$ o Aumenta-se a pena de 1/3 (um terço) se o agente comete o crime:

I - no exercício de cargo ou função pública ou a pretexto de exercê-la;

II - prevalecendo-se de relações domésticas, de coabitação ou de hospitalidade; ou

III - prevalecendo-se de relações de parentesco consangüíneo ou afim até o terceiro grau, ou por adoção, de tutor, curador, preceptor, empregador da vítima ou de quem, a qualquer outro título, tenha autoridade sobre ela, ou com seu consentimento.

O primeiro tipo previsto no Estatuto da Criança e Adolescente visa evitar o envolvimento de menores em produções de entretenimento sexual, assim, incriminando diversas condutas atinentes à elaboração direta de conteúdo dessa natureza, a saber, "produzir", "reproduzir", “dirigir", "fotografar", "filmar" ou "registrar".

Logo, ante a multiplicidade de verbos nucleares, trata-se de tipo misto alternativo, de modo que qualquer das ações previstas é suficiente

40 TOLEDO, Francisco de Assis. Princípios Básicos de Direito Penal. $5^{\mathrm{a}}$ ed., São Paulo: Saraiva, 1994. p. 21. 
para a consumação do delito, ao passo que a prática de mais de uma conduta, no mesmo contexto, implicará no cometimento de crime único.

Produzir significa dar origem, gerar ou financiar; reproduzir é produzir novamente ou copiar algo sob imitação, ou seja, modificar fotos e filmes em relação à versão original; fotografar e filmar correspondem às suas acepções coloquiais; e registrar traduz o lançamento do conteúdo fotográfico ou visual em base de dados apropriada à reprodução de informações.

Cumpre destacar que o agente que pratica o delito em comento e, após, armazena o conteúdo produzido, apenas responde pelo art. 240, afastando-se a incidência do art. 241-B, pois a conduta de armazenamento, perpetrada após o cometimento do crime principal, no mesmo contexto fático, constitui ato posterior não punível, representando mero exaurimento do crime mais grave.

Entretanto, haveria a aplicação cumulativa dos tipos na hipótese de o sujeito ativo armazenar fotos pornográficas de um menor que ele mesmo fotografou (art. 240) e possuir fotos de outro menor em cena pornográfica sobre a qual ele não teve participação (art. 241-B).

Vale destacar que o $\S 1^{\circ}$ do art. 240 também tipificou condutas de agentes que indiretamente contribuem para a promoção do conteúdo inadequado, equiparando às condutas do caput o papel destes, que, em tese, seriam partícipes do delito, mas que foram transformados em autores em razão da construção do tipo básico.

Ressalte-se o equívoco cometido pelo legislador ao incluir na redação do tipo a conduta daquele que contracena com criança ou adolescente em cena pornográfica ou de sexo explícito, tendo em conta que tal cenário urge a incidência do crime de estupro de vulnerável, havendo, portanto, o necessário concurso material com o art. 218-A do Código Penal. 
$\mathrm{Na}$ mesma linha do $\mathrm{CP}$, todos os crimes do ECA podem ser praticados por qualquer pessoa. Em relação ao delito em apreço, eventual circunstância especial do agente em relação à vítima representará causa de aumento de pena, conforme consubstancia o $\S 2^{\circ}$ do art. 240.

Nesse sentido, a pena será majorada de $1 / 3$ caso o sujeito ativo pratique o delito em qualquer das circunstâncias apontadas, que incluem o exercício de cargo ou função pública ou o pretexto de exercê-la e o prevalecimento tanto da inclusão no núcleo de convivência da vítima quanto de relação de parentesco ou de autoridade em face da mesma.

Muito embora a redação antiga do art. 240 cominasse sanção mais gravosa caso o agente possuísse o intuito de obter de vantagem patrimonial, o tipo atual não requer qualquer elemento subjetivo específico, bastando o dolo, ou seja, a vontade consciente, de incidir na conduta tipificada. As considerações traçadas quanto ao dolo se aplicam a todos os delitos a serem analisados no item 3.2, salvo o crime previsto no art. 241-D, que requer dolo específico.

Importante frisar que se trata de crime de perigo abstrato, eis que se presume o dano à formação moral da criança e do adolescente, sendo desnecessário comprovar a sua efetiva ocorrência. Admite-se a tentativa e não se pune a forma culposa, o que se aplica aos demais delitos a serem examinados em seguida.

\subsubsection{Comercialização de qualquer de registro com conotação sexual envolvendo criança ou adolescente}

Art. 241. Vender ou expor à venda fotografia, vídeo ou outro registro que contenha cena de sexo explícito ou pornográfica envolvendo criança ou adolescente:

Pena - reclusão, de 4 (quatro) a 8 (oito) anos, e multa. 
Ao editar o art. 241, o legislador almejou coibir o comércio de conteúdo lascivos envolvendo criança ou adolescente, assim, criminalizouse a conduta do mercante de fotos ou imagens de menores envolvidos em contextos libidinosos, ao passo que o ato do adquirente está capitulado no art. 241-B, conforme se verá mais adiante.

Enfatize-se que a consumação do delito independe da efetiva venda do material (alienação por determinado preço), haja vista que também é típico o ato de expor à venda, isto é, a mera apresentação de objeto alvo de alienação.

Novamente, o legislador não impôs nenhum elemento subjetivo específico à figura típica, bastando o dolo, ou seja, a vontade consciente de incidir na conduta. Vale destaque, também, que embora o tipo preveja a venda do conteúdo pornográfico, o que, em geral, resulta na percepção de vantagem patrimonial, não se exige o ânimo de lucro para a consumação do crime.

Por fim, interessante destacar que a competência para apuração do delito em comento será da Justiça Federal, nos termos do art. 109, V, da Constituição Federal, caso o trânsito do conteúdo impróprio extravase as fronteiras nacionais, ao passo que, se o delito se restringir à comunicação eletrônica entre duas pessoas residentes no Brasil, o feito incumbirá à Justiça Estadual.

\subsubsection{Distribuição ou divulgação de qualquer registro que contenha cena de sexo explícito ou pornográfica envolvendo criança ou adolescente}

Art. 241-A. Oferecer, trocar, disponibilizar, transmitir, distribuir, publicar ou divulgar por qualquer meio, inclusive por meio de sistema de informática ou telemático, fotografia, vídeo ou outro registro que contenha cena de sexo explícito ou pornográfica envolvendo criança ou adolescente:

Pena - reclusão, de 3 (três) a 6 (seis) anos, e multa. 
$\S 1^{\circ}$ Nas mesmas penas incorre quem:

I - assegura os meios ou serviços para o armazenamento das fotografias, cenas ou imagens de que trata o caput deste art.;

II - assegura, por qualquer meio, o acesso por rede de computadores às fotografias, cenas ou imagens de que trata o caput deste art..

$\S 2^{\circ}$ As condutas tipificadas nos incisos I e II do $§ 1^{\circ}$ deste art. são puníveis quando o responsável legal pela prestação do serviço, oficialmente notificado, deixa de desabilitar o acesso ao conteúdo ilícito de que trata o caput deste art..

O dispositivo alhures tem por escopo tolher a circulação de fotos, vídeos ou registros cujo objeto seja criança ou adolescente em cena de sexo explícito ou em cenário pornográfico.

A norma atinge em especial a Internet, mas também se aplica a todos os meios de comunicação, de modo que nada impede que se puna a mantença de qualquer tipo de rede de computadores que possibilite o acesso ao material obsceno, como, por exemplo, a rede interna de uma empresa.

Trata-se de tipo misto alternativo, contendo inúmeras condutas aptas a ensejar a consumação do crime, a saber, "oferecer" (apresentar para aceitação), “trocar” (permutar determinado bem por outro), “disponibilizar" (tornar acessível para aquisição), "transmitir" (remeter de um local a outro), "distribuir" (franquear a diversas pessoas), "publicar" (tornar amplamente público) ou "divulgar" (difundir, ainda que de forma implícita), todos referentes à exposição da matéria imoral ${ }^{41}$.

Ademais, os incisos do $\S 1^{\mathrm{o}}$ da norma preveem expressamente a punição do partícipe, seja por proporcionar mecanismos para acúmulo do material, seja por assegurar acesso a tal conteúdo por qualquer meio.

A previsão do inciso I abarca, por exemplo, pessoa que detém computadores com elevada capacidade de armazenamento e, portanto,

\footnotetext{
${ }^{41}$ NUCCI, Guilherme de Souza. Estatuto da Criança e do Adolescente Comentado: em busca da Constituição Federal das Crianças e dos Adolescentes. $3^{a}$ ed., Rio de Janeiro: Forense, 2017. p. 785.
} 
franqueia maiores opções àquele que insere as cenas lascivas nos meios de comunicação.

Já o inciso II alcança o "partícipe ligado à mantença de sites, que hospedam o material inadequado, a ser visualizado por terceiros, usuários da Internet" 42 , podendo, inclusive, atingir "o provedor, que possibilita o acesso à Internet, bem como a navegação de sites de conteúdo indevido, como também o criador do site, hospedeiro do material pornográfico"43.

Cumpre destacar que o $\S 2^{\circ}$ do art. 241-A contém condição objetiva de punibilidade das condutas tipificadas nos incisos supra, de forma que as mesmas só serão puníveis caso o responsável legal pelo serviço prestado, uma vez notificado, não retire o conteúdo ilícito dentro do prazo estipulado na intimação oficial. Logo, há a possibilidade de se evitar a punição penal caso o serviço seja desabilitado tempestivamente.

O legislador demonstrou cautela ao inserir tal previsão, mostrando-se sabedor de que a Internet conta com amplo volume de informações, de maneira que é inviável aos provedores de acesso e aos mantenedores de sites o conhecimento de todo o material que circula na rede, tampouco a fiscalização ininterrupta do seu conteúdo.

Ainda que tal dispositivo possa beneficiar profissionais de tecnologia que atuem como partícipes do delito, sendo coniventes com a divulgação dos registros pornográficos envolvendo menor, a inserção da dita formalidade legal aparenta ser positiva, eis que salvaguarda os técnicos idôneos que desconheçam o teor lascivo dos registros, facultando-lhes a possibilidade de sustar a ilicitude, uma vez notificados e, portanto, cientes de sua ocorrência.

Cumpre frisar que a lei prevê a notificação da figura do responsável legal pela prestação do serviço de acesso ou de armazenamento, logo, a intimação deve ser direcionada àquele que seja legalmente capaz de

\footnotetext{
${ }^{42}$ NUCCI, 2017, p. 787.

${ }^{43}$ Ibid., p. 787.
} 
responder em nome da empresa, detendo poder de mando e possibilidades reais de ordenar a interrupção do meio de acesso.

Além disso, a intimação deve ser emitida por autoridade competente para a apuração do delito, tal como a autoridade policial, o juiz criminal ou o promotor da Infância e da Juventude, de modo que comunicações remetidas por ONG, cartas enviadas pela família da vítima ou mesmo reportagens veiculadas em meios de comunicação não configuram espécies de notificação oficial.

Dessa forma, uma vez alertado quanto ao material ilícito, o responsável legal deve desabilitar o acesso, não o fazendo demonstra que a mantença do meio ou do serviço de acesso lhe é vantajosa, restando, portanto, presente a condição para punir.

Interessante destacar que, no âmbito processual, a condição objetiva de punibilidade, isto é, a notificação, se traduz em condição de procedibilidade, de modo que, embora a instauração de inquérito seja possível, o indiciamento dos autores ou partícipes, bem como o oferecimento de denúncia ou queixa, antes do decurso estipulado na intimação, constituirá manifesto constrangimento ilegal.

Em suma, decorrido o prazo da notificação que tenha sido realizada com sucesso, a condição estará preenchida e o fato será punível, valendo ressaltar que a desativação intempestiva não obsta a consumação do crime.

Assim como nos tipos analisados acima, o elemento subjetivo do tipo se exaure no dolo de praticar a conduta típica, não havendo elemento específico.

\subsubsection{Aquisição ou posse de registro que contenha cena de sexo explícito ou pornográfica envolvendo criança ou adolescente}

Art. 241-B. Adquirir, possuir ou armazenar, por qualquer meio, fotografia, vídeo ou outra forma de registro que contenha cena de sexo explícito ou pornográfica envolvendo criança ou adolescente: 
Pena - reclusão, de 1 (um) a 4 (quatro) anos, e multa.

§1ํo A pena é diminuída de 1 (um) a 2/3 (dois terços) se de pequena quantidade o material a que se refere o caput deste art..

$\S 2^{\circ}$ Não há crime se a posse ou o armazenamento tem a finalidade de comunicar às autoridades competentes a ocorrência das condutas descritas nos arts. 240, 241, 241-A e 241-C desta Lei, quando a comunicação for feita por:

I - agente público no exercício de suas funções;

II - membro de entidade, legalmente constituída, que inclua, entre suas finalidades institucionais, o recebimento, o processamento e o encaminhamento de notícia dos crimes referidos neste parágrafo;

III - representante legal e funcionários responsáveis de provedor de acesso ou serviço prestado por meio de rede de computadores, até o recebimento do material relativo à notícia feita à autoridade policial, ao Ministério Público ou ao Poder Judiciário.

$\S 3^{\circ}$ As pessoas referidas no $\S 2^{\circ}$ deste art. deverão manter sob sigilo o material ilícito referido.

A norma acima colacionada tem por finalidade alcançar aquele que, dolosamente, "adquire", "possui" ou "armazena" material pornográfico figurando menor de 18 (dezoito) anos, podendo o sujeito ativo ser qualquer pessoa.

Interessante destacar que o quantum de pena cominada ao delito torna admissível a suspensão condicional do processo, benefício previsto para delitos cuja pena mínima cominada seja igual ou inferior a 1 (um) ano, desde que presentes os demais requisitos legais (art. 89 da Lei 9.099/95). Em hipótese de condenação por pena não superior a 2 (dois) anos, nos termos do art. 77 do $\mathrm{CP}$, será aplicável a suspensão condicional da pena, caso o indivíduo atenda às outras exigências consubstanciadas na norma. Por fim, tendo em vista não se tratar de crime praticado com violência ou grave ameaça à pessoa, cabível a substituição da pena privativa de liberdade, nos moldes do art. 44 do Código Penal, salvo se o agente for 
reincidente em crime doloso ou se as suas condições pessoais indicarem a insuficiência da substituição.

Tudo quanto exposto em relação aos benefícios penais aplica-se aos delitos dos arts. 241-C e 241-D, eis que as penas dos mesmos corresponde a reclusão, de 1 (um) a 3 (três) anos, e multa.

No $\S 1^{\circ}$ do artigo em comento, o legislador inseriu causa de diminuição de pena a ser aplicada quando a quantidade de material apreendido for pequena, devendo a diminuição ser modulada, de 1 (um) a 2/3 (dois terços), sendo a redução maior quão mais ínfima for a coleção pornográfica.

Já o §2 da norma prevê excludentes de ilicitude ao dispor que não há crime quando o armazenamento for realizado por agente público, membro de entidade de proteção ao menor ou representante legal ou funcionário do provedor, visando à denúncia de delitos envolvendo pornografia infanto-juvenil.

Em boa verdade, tal conduta corresponde ao estrito cumprimento de dever legal de tais figuras, excludente já prevista, de forma genérica, no art. 23, III, do Código Penal. Ressalte-se que, conforme preceitua o art. $5^{\circ}$, I, $\S 3^{\circ}$, do CPP, "qualquer pessoa do povo que tiver conhecimento da existência de infração penal em que caiba ação pública poderá, verbalmente ou por escrito, comunicá-la à autoridade policial", logo, qualquer pessoa poderá armazenar o conteúdo ilícito para tal finalidade, estando abarcada pelo exercício regular de direito.

Por derradeiro, cumpre asseverar que a lei impõe dever de sigilo aos comunicantes, de modo que o material ilícito armazenado deve ser mantido em confidência, haja vista que a violação dolosa de tal preceito pode significar a configuração do crime disposto no art. 241-A. 


\subsubsection{Simulação do envolvimento de criança e adolescente em cena de sexo explícito ou pornográfica}

Art. 241-C. Simular a participação de criança ou adolescente em cena de sexo explícito ou pornográfica por meio de adulteração, montagem ou modificação de fotografia, vídeo ou qualquer outra forma de representação visual:

Pena - reclusão, de 1 (um) a 3 (três) anos, e multa.

Parágrafo único. Incorre nas mesmas penas quem vende, expõe à venda, disponibiliza, distribui, publica ou divulga por qualquer meio, adquire, possui ou armazena o material produzido na forma do caput deste art..

$\mathrm{O}$ art. 241-C torna típica a conduta do agente que cria imagens dissimuladas abrangendo menores de 18 (dezoito) anos, eis que a divulgação de tais imagens, ainda que falsas, causa prejuízo aos menores retratados, bem como estimula a busca de cenas reais envolvendo o segmento juvenil.

Simular significa representar algo com aparência de realidade, o que pode ser feito através de "adulteração" (espécie de falsificação), "montagem" (reunião de elementos) ou "modificação" (alterar ou transformar).

No presente contexto, a simulação é praticada por agente que, na posse de material pornográfico envolvendo maiores de idade, promove a modificação de tal conteúdo para que os protagonistas das referidas cenas passem a ser crianças ou adolescentes.

Equipara-se ao caput a conduta daquele que, em relação ao material simulado, "vende, expõe à venda, disponibiliza, distribui, publica ou divulga por qualquer meio, adquire, possui ou armazena" o conteúdo, verbos que correspondem ao núcleo dos tipos dos arts. 241, 241-A e 241-B. 


\subsubsection{Atrair criança com a finalidade de com ela praticar ato libidinoso}

Art. 241-D. Aliciar, assediar, instigar ou constranger, por qualquer meio de comunicação, criança, com o fim de com ela praticar ato libidinoso:

Pena - reclusão, de 1 (um) a 3 (três) anos, e multa.

Parágrafo único. Nas mesmas penas incorre quem:

I - facilita ou induz o acesso à criança de material contendo cena de sexo explícito ou pornográfica com o fim de com ela praticar ato libidinoso;

II - pratica as condutas descritas no caput deste art. com o fim de induzir criança a se exibir de forma pornográfica ou sexualmente explícita.

A figura típica constante do art. 241-D abarca a conduta do sujeito que percorre diversas modalidades de meios de comunicação para encontrar crianças disponíveis para o sexo. Logo, o legislador preocupou-se em repreender o agente que se comunica com infantos, por meio de salas de bate-papo, mensagens eletrônicas, sites, dentre outros instrumentos, com a finalidade de atraí-las para o contato sexual, seja por intermédio de aliciamento (seduzir, atrair), de assédio (importunar), de instigação (fomentar) ou de constrangimento (obrigar pela força).

Observe-se que o tipo ilustrado é preventivo, punindo a atividade de captação do menor para a prática lasciva, assim, buscando evitar a ocorrência do tipo mais grave que decorreria do efetivo envolvimento sexual. No ensejo, saliente-se que a consumação do art. 241-D independe da ocorrência de relação sexual, até porque, em tal hipótese, invocar-se-ia o art. 217-A do Código Penal.

O dispositivo ora em comento possui algumas particularidades em relação aos demais inseridos no presente capítulo, sobretudo no que tange aos sujeitos do delito e ao dolo do agente. 
Nesse sentido, imprescindível destacar que o adolescente não foi incluído na redação do tipo, de modo que o polo passivo se restringe à criança, ou seja, ao menor de 12 (doze) anos, pois entende-se que, na maior parte dos casos, os jovens já possuiriam elementos cognitivos suficientes para evitar o assédio virtual. Quanto ao sujeito ativo, mantém-se a possibilidade de o mesmo ser qualquer pessoa.

Além disso, o delito em comento possui elemento subjetivo específico, consistente na finalidade de praticar ato libidinoso com a criança.

Incorre nas mesmas penas do caput aquele que, com o mesmo dolo específico supracitado, "facilita" ou "induz" o acesso do impúbere a material lascivo, conforme preconiza o inciso I, do parágrafo único.

Trata-se, essencialmente, de desdobramento da figura principal, pois o agente busca, de forma camuflada, isto é, por meio de apresentação de conteúdo pornográfico ao menor, atrair a criança para o contato libidinoso.

Por sua vez, o inciso II, do parágrafo único, compreende os mesmos verbos nucleares do caput, havendo, inclusive, referência expressa ao mesmo. O que distingue ambos é o dolo do agente, tendo em vista que, nesta hipótese, o elemento subjetivo específico é a finalidade de obter cenas pornográficas ou de sexo explícito de infante, não pretendendo o agente manter relacionamento sexual com a criança.

Dessa forma, a infração penal contida no inciso II almeja tolher a atividade daquele que aspira conseguir registros do menor de 12 (doze) anos em contexto lascivo, tratando-se, portanto, de tipo preventivo voltado a evitar a configuração das figuras típicas dispostas nos arts. 240, 241 e 241-A. 


\subsection{A ação penal nos crimes contra a dignidade sexual da infanto- juventude}

Art. 225. Nos crimes definidos nos Capítulos I e II deste Título, procede-se mediante ação penal pública condicionada à representação.

Parágrafo único. Procede-se, entretanto, mediante ação penal pública incondicionada se a vítima é menor de 18 (dezoito) anos ou pessoa vulnerável.

A Lei 12.015/2009 alterou o artigo colacionado supra, invertendo a natureza da ação penal nos crimes contra a liberdade sexual e contra vulnerável, que, outrora, era de iniciativa privada. Entretanto, a referida alteração foi maculada por crasso erro de técnica legislativa, eis que o caput e o parágrafo único possuem textos flagrantemente contraditórios.

Nesse diapasão, ao passo que o primeiro dispõe que nos crimes inseridos no capítulo II ("Dos crimes sexuais contra vulnerável”) a ação penal será pública e condicionada à representação, o último prevê que a ação será pública e incondicionada caso a vítima seja menor de idade ou pessoa vulnerável.

Dito isso, percebe-se que o texto legal é paradoxo, apenas estando em síntese ao prever o Ministério Público como dominus litis. A manifesta ilogicidade do legislador despertou as mais variadas interpretações quanto à natureza da ação penal nos delitos contra a dignidade sexual da infantojuventude.

Por um lado, há quem sustente que o caput deve prevalecer, aduzindo, para tanto, que ante duas previsões conflitantes e impassíveis de compatibilização, preponderará a norma mais liberal, já que em termos de direito penal material não se pode optar pela disposição mais grave. Aponta-se, ainda, que o caput seria duplamente mais vantajoso, eis que conferiria à vítima o predomínio de seu interesse sobre o interesse público, e, ao mesmo tempo, beneficiaria o infrator por não haver obrigatoriedade da 
ação penal. Dentre os paladinos dessa corrente, cabe destacar Cezar Roberto Bitencourt ${ }^{44}$.

Por outro lado, Rogério Greco, invocando os princípios da proibição de excesso e da proteção deficiente, sustenta que a ação será pública e incondicionada, interpretando que o condicionamento à representação limitar-se-ia aos crimes contidos no capítulo I ("Dos crimes contra a liberdade sexual" $)^{45}$.

Nessa mesma linha, colha-se o entendimento do Desembargador Paulo Rangel:

Pensamos que o que se quis dizer (aqui o terreno é movediço: adivinhar o que o legislador quis dizer) no caput do art. 225, é que nos crimes definidos no capítulo I (apenas o capítulo I) a ação penal será pública condicionada à representação, e no parágrafo único do mesmo artigo, será pública incondicionada quando a vítima for pessoa menor de 18 anos ou pessoa vulnerável ${ }^{46}$.

A visão defendida por Bitencourt é problemática na medida em que, ao condicionar a ação penal, ignora por completo que, muitas das vezes, o autor dos delitos de cunho sexual é exatamente responsável legal da vítima vulnerável, a quem competiria o exercício da representação, de modo que a primazia dessa perspectiva resultaria na desproteção do incapaz.

Convém destacar a interpretação conciliadora proposta pelo Ministro Sebastião Reis Júnior, o qual pontuou que a ação penal seria sempre incondicionada em relação à vítima possuidora de vulnerabilidade intrínseca e permanente, ao passo que, em se tratando de vulnerabilidade transitória, sendo o indivíduo incapaz de oferecer resistência apenas na ocasião da ocorrência dos atos libidinosos, a ação seria condicionada à representação da vítima, da qual não se poderia remover a escolha de evitar o o strepitus judicii. Veja-se, nesse sentido, excertos do acórdão aprovado pela Sexta Turma:

\footnotetext{
${ }^{44}$ BITTENCOURT, 2017, p. 157.

${ }^{45}$ GRECO, 2010, p. 638.

${ }^{46}$ RANGEL, Paulo. Direito Processual Penal. $17^{\mathrm{a}}$ ed., Rio de Janeiro: Lumen Juris, 2009. p. 301.
} 
5. De acordo com o art. 225 do Código Penal, o crime de estupro, em qualquer de suas formas, é, em regra, de ação penal pública condicionada à representação, sendo, apenas em duas hipóteses, de ação penal pública incondicionada, quais sejam, vítima menor de 18 anos ou pessoa vulnerável.

6. A própria doutrina reconhece a existência de certa confusão na previsão contida no art. 225, caput e parágrafo único, do Código Penal, o qual, ao mesmo tempo em que prevê ser a ação penal pública condicionada à representação a regra tanto para os crimes contra a liberdade sexual quanto para os crimes sexuais contra vulnerável, parece dispor que a ação penal do crime de estupro de vulnerável é sempre incondicionada.

7. A interpretação que deve ser dada ao referido dispositivo legal é a de que, em relação à vítima possuidora de incapacidade permanente de oferecer resistência à prática dos atos libidinosos, a ação penal seria sempre incondicionada. Mas, em se tratando de pessoa incapaz de oferecer resistência apenas na ocasião da ocorrência dos atos libidinosos, a ação penal permanece condicionada à representação da vítima, da qual não pode ser retirada a escolha de evitar o strepitus judicii.

8. Com este entendimento, afasta-se a interpretação no sentido de que qualquer crime de estupro de vulnerável seria de ação penal pública incondicionada, preservando-se o sentido da redação do caput do art. 225 do Código Penal.

9. No caso em exame, observa-se que, embora a suposta vítima tenha sido considerada incapaz de oferecer resistência na ocasião da prática dos atos libidinosos, esta não é considerada pessoa vulnerável, a ponto de ensejar a modificação da ação penal. Ou seja, a vulnerabilidade pôde ser configurada apenas na ocasião da ocorrência do crime. Assim, a ação penal para o processamento do crime é pública condicionada à representaçãa $0^{47}$.

Por derradeiro, cumpre asseverar que a Lei 12.650/2012 conferiu prazo prescricional diferenciado aos crimes abordados no presente ensaio, tendo, a partir de alteração promovida no art. 111 do Código Penal, disposto que a prescrição intercorrente será computada "nos crimes contra a dignidade sexual de crianças e adolescentes, previstos neste Código ou em legislação especial, da data em que a vítima completar 18 (dezoito) anos, salvo se a esse tempo já houver sido proposta a ação penal” (art. 111, V, do $\mathrm{CP})$.

\footnotetext{
${ }^{47}$ STJ, Habeas Corpus n. 276.510/RJ, Rel. Ministro Sebastião Reis Júnior, Sexta Turma, Data de julgamento 11/11/2014, DJe 01/12/2014.
} 


\section{CAPÍTULO 4 - A PEDOFILIA}

\subsection{Origem histórica}

A perversão sexual por crianças e adolescentes não é algo novo.

No passado, tal comportamento era difundido e socialmente aceito, tendo se estendido, na antiguidade clássica - período compreendido entre o século VIII a.C. e a queda do império Romano Ocidental, no ano 476 -, pelo Egito, Assíria, Pérsia, Arábia, e, sobretudo, pelas civilizações mais notáveis da época, a saber, Grécia e Roma antiga.

Nesse ponto, cumpre fazer alusão ao famigerado diálogo de Platão, "O Banquete"48, narrado por Apolodoro e ambientado durante jantar ateniense oferecido pelo poeta Agatão, em que Sócrates e Aristófanes, dentre outros, discursam sobre o amor, ao manifestarem admiração à figura de Eros.

$\mathrm{Na}$ obra, os personagens falam sobre o afeto ao efebo, termo que designa jovem do sexo masculino que acompanhava os veteranos da milícia para absorver o espírito militar, a aptidão física ideal, bem como para a iniciação na vida sexual e social, sendo comum que os mancebos não se separassem de seus mestres nem para dormir, acabando por lhes satisfazer os anseios eróticos. No ensejo, Platão também menciona sua entrega a Sócrates, que foi seu professor.

Herdeira legítima da cultura helênica, Roma também importou a prática, só que lá os meninos sodomizados eram denominados concubini e, geralmente, de casta inferior em relação ao seu agressor. Desse modo, os senhorios tinham sobre eles o poder de vida e morte, servindo-se dos mesmos para satisfazer suas necessidades sexuais, como se escravos do sexo fossem.

${ }^{48}$ PLATÃO. O Banquete, ou, Do amor. SOUZA, José Cavalcante de. (Trad.). Rio de Janeiro: DIFEL, 2008. 
Os povos chinês e muçulmano também não foram alheios à tais abusos, eis que, durante boa parte da história, o primeiro operava o tráfico de crianças para fins sexuais e o último se valia dos menores de idade como subterfúgio para atender a desejos libidinosos censurados pela religião.

Sobre o tema, esclarece, o filósofo e escritor, Olavo de Carvalho:

Na Grécia e no Império Romano, o uso de menores para a satisfação sexual de adultos foi um costume tolerado e até prezado. Na China, castrar meninos para vendê-los a ricos pederastas foi um comércio legítimo durante milênios. No mundo islâmico, a rígida moral que ordena as relações entre homens e mulheres foi não raro compensada pela tolerância para com a pedofilia homossexual. Em alguns países isso durou até pelo menos o começo do século $\mathrm{XX}$, fazendo da Argélia, por exemplo, um jardim das delícias para os viajantes depravados ${ }^{49}$.

Importante destacar, também, que o casamento infantil, outrora, era rotineiro. Exemplo patente disso extrai-se da Grécia e Roma antiga, onde a maridagem e a maternidade precoces eram incentivadas, haja vista que a expectativa de vida era em torno dos 45 (quarenta e cinco) anos de idade, logo, a antecipação de tais ritos de passagem era corriqueira ${ }^{50}$.

Já na Idade Média, sob o regime da lei civil inglesa, derivada das leis romanas, o casamento antes dos 16 (dezesseis) anos era comum, bem assim na China Imperial o conúbio infantil era a norma ${ }^{51}$.

Frise-se que, historicamente, as religiões influenciaram a idade considerada adequada para o matrimônio, cabendo enfatizar que o Direito Canônico vedava o enlace antes da puberdade, ao dispor, no cânone 1083, que "o homem antes do dezesseis (16) anos completos e a mulher antes dos quatorze (14) também completos não podem contrair matrimônio válido"52.

\footnotetext{
49 CARVAlHO, Olavo de. Cem Anos de Pedofilia. Disponível em: <http://www.olavodecarvalho.org/cem-anos-de-pedofilia/>. Acesso em: 22 abr. 2018.

${ }^{50}$ LAIOU, Abgeliki. Coercion to sex and marriage in ancient and medieval societies. Washington, DC: Harvard University Press, 1998. p. 85-190.

${ }^{51}$ SAITO, Osamu. Historical demography: achievements and prospects. v. 50, n. 3. Population Studies, 1996. p. 537-553.

52 Disponível em: <http://www.vatican.va/archive/cod-iuris-canonici/portuguese/codex-iuriscanonici_po.pdf>. Acesso em: 22 abr. 2018.
} 
Isto posto, pode-se argumentar que a moléstia sexual em face de menores de idade recuou a partir de uma postura do cristianismo, tendo a prática sido coibida em toda a Europa ao cabo da Idade Medieval, eis que a Igreja Católica, dominante à época, só reputava o ato sexual como moralmente aceito se inserido no âmbito conjugal, entre homem e mulher, hipóteses outras eram tidas como pecaminosas e ensejadoras de condenação no purgatório.

Dessa forma, a noção de heresia e castigo disseminada pelo clero culminou no advento da concepção de pecado sexual, incutindo, portanto, culpa e medo à conjunção carnal praticada fora do casório e, por conseguinte, mesmo que não deliberadamente, protegendo a criança em um período de ampla exposição aos desejos carnais de adultos ${ }^{53}$.

Outro fator que contribuiu para o enfrentamento das agressões sexuais foi o advento da Renascença, período antropocêntrico que sucedeu a Idade Média e que, por meio do humanismo, promoveu a valorização do ser humano.

Nesse contexto, a criança passa a ocupar posição de relevo no seio familiar, tornando-se, o filho, objeto de investimento existencial dos pais. Sendo assim, a família se apresenta como lugar de afetividade e de atenção à infância, encetando, tais laços sentimentais, incipiente combate à negligência milenar para com a infanto-juventude ${ }^{54}$.

As breves considerações ora traçadas almejam, apenas, ilustrar que 0 desrespeito à dignidade sexual das crianças e adolescentes não é um tema enfrentado pela atualidade, mas, muito ao revés, questão presente nas mais variadas sociedades e culturas ao longo da história, e que se deparou, com a evolução humana, com transformações do ponto de vista valorativo social.

\footnotetext{
${ }^{53}$ GOFF, Jacques Le. O Nascimento do Purgatório. AZEVEDO, Maria Fernanda Gonçalves de (Trad.). São Paulo: Estampa, 1981. p. 142.

${ }^{54}$ ARÍES, Philippe; DUBY, Georges. História da Vida Privada - Da Renascença ao Século das Luzes. Hildegard Fiest (Trad.). São Paulo: Companhia das Letras, 1991. p. 15.
} 


\subsection{Conceito clínico e falácias terminológicas}

Coloquialmente, o termo "pedofilia" é empregado para apontar qualquer relação sexual havida entre um adulto e um vulnerável, entretanto, tal acepção é falaciosa, eis que o vocábulo possui conceito clínico.

Em termos médicos, trata-se de transtorno mental tipificado tanto na CID (Classificação Estatística Internacional de Doenças e Problemas Relacionados com a Saúde), correspondendo ao código F65.4, quanto em tratados de Psiquiatria, sob a numeração 302.2.

Nessa esteira, de acordo com o DSM-IV ${ }^{55}$ - manual de diagnósticos elaborado pela Associação de Psiquiatria Americana -, a pedofilia é uma variedade de parafilia, categoria que reúne os transtornos sexuais e da identidade de gênero.

Tal grupo é caracterizado por possuir:

Fantasias, anseios sexuais ou comportamentos recorrentes, intensos e sexualmente excitantes, em geral envolvendo objetos não humanos, sofrimento ou humilhação próprio ou do parceiro, crianças, ou outras pessoas sem o seu consentimento ${ }^{56}$.

Dentre as parafilias, há, além da pedofilia, a necrofilia (atração sexual por cadáveres); a zoofilia (atração sexual por animais); coprofilia (atração sexual relacionada às fezes); menofilia (atração sexual por mulheres menstruadas); o voyeurismo (satisfação da libido por meio da observação de pessoa em contexto erótico); sadismo (prazer sexual com o sofrimento físico de outrem); exibicionismo (satisfação da lascívia através da exibição da própria nudez), entre outros.

Apesar das particularidades que lhe são inerentes, todas as perversões elencadas podem ser caracterizadas pela presença de intensas e repetidas fantasias sexuais que, por serem excessivas do ponto de vista

\footnotetext{
${ }^{55}$ BATISTA, Dayse. Dsm-IV: manual de diagnostico e estatístico de transtornos mentais. $4^{\mathrm{a}}$ ed., Porto Alegre: Artes Médicas, 1995. p. 495.

${ }^{56}$ Ibid., p. 495.
} 
médico, acarretam significativo mal-estar clínico, dano social ou ocupacional.

Cumpre assinalar que nem toda parafilia interessará à Lei, já que algumas delas não afetam a sociedade, tampouco culminam na vitimização de terceiros, assim, não exigindo qualquer grau de reprovação.

Contudo, a assertiva não se aplica à universalidade, face ao efeito devastador que determinadas disfunções - tal como a pederastia -, podem acarretar no corpo social, demandando, portanto, a intervenção do Direito Penal.

Entretanto, incorreto afirmar que nossa legislação tipifica a pedofilia, tendo em vista que o que resta criminalizado são condutas de perversão sexual contra crianças e adolescentes, as quais podem ser perpetradas tanto por quem apresenta distúrbio pedófilo, quanto por indivíduos psiquiatricamente hígidos.

Em outras palavras, nem todo abusador é pedófilo, e nem todo pedófilo pratica crimes sexuais.

Imprescindível destacar que estudos apontam que a enorme maioria dos algozes sexuais da infanto-juventude não são portadores de pedofilia, sendo esses o que se denomina de "infratores situacionais", como se verá adiante.

Nesse exato sentido, destaque-se pesquisa realizada por psiquiatras da seara criminológica, Michael Seto e Martin L. Lalumière, intitulada "A Brief Screening Scale do Identify Pedophilic Interests Among Child Molesters" ${ }^{\prime 57}$, a qual concluiu que só $27 \%$ de tais infratores são pedófilos, significando que $73 \%$ dos entrevistados não sofriam com a disfunção psicopatológica em comento.

\footnotetext{
57 Disponível em: <http://journals.sagepub.com/doi/abs/10.1177/107906320101300103>. Acesso em: 22 abr. 2018.
} 
Estudo publicado pelo Journal of the European Psychiatry Association serve de esteio a tais estatísticas, corroborando com a tese ao atestar que apenas 16,2\% dos criminosos interrogados - 146 (cento e quarenta seis) homens que cometeram abusos sexuais contra crianças e adolescentes entre os anos de 2005 e 2012 -, se enquadrariam no diagnóstico de pedofilia segundo os critérios propostos pelo DSM-IV ${ }^{58}$.

Ademais, o Governo holandês publicou relatório cuja constatação é idêntica, isto é, assentando que tão-só $20 \%$ dos transgressores sexuais que alvejam os jovens padecem de alguma forma de parafilia, dentre as quais a pedofilia, de modo que mais de $80 \%$ seriam não-pedófilos. O informe em apreço evidenciou, outrossim, que indivíduos sem perversão sexual pedófila são mais propensos a empregar violência ao perpetrar abusos libidinosos contra vulneráveis ${ }^{59}$.

Isto posto, explícita a necessidade de se insistir no emprego da nomenclatura correta no que tange ao tópico apreciado, sob o risco de gerar compreensões levianas a respeito de patologia séria e inexorável àqueles que acomete.

Não é o outro o juízo da Interpol, tendo a organização, em 2016, através de seu sítio eletrônico, emitido nota reconhecendo a importância da utilização harmônica, ao tratar da exploração e abuso sexuais dos impúberes, de termos e definições precisos e internacionalmente reconhecidos.

No bojo da manifestação, a entidade intergovernamental atestou que implementaria a recém desenvolvida, à época, Diretriz de Luxemburgo, bem como declarou que recomendaria, aos seus 190 (cento e noventa) países membros, a aplicação daquele conteúdo, já que o documento oferece referências terminológicas voltadas a desvendar o labiríntico léxico

\footnotetext{
58 Disponível em: <http://www.europsy-journal.com/article/S0924-9338\%2814\%29777314/abstract>. Acesso em: 22 abr. 2018.

59 Disponível em: <https://www.dutchrapporteur.nl/binaries/dutch-rapporteur.on-solidground.tackling-sexual-violence-against-children.2014_tcm24-35335.pdf>. Acesso em: 22 abr. 2018.
} 
pertinente ao tema, de modo a garantir que as polícias do mundo estão 'falando a mesma língua' 60 .

A simples leitura da Cartilha de Orientações Terminológicas ${ }^{61}$ é esclarecedora, convindo apontar que, à página 85, os infratores sexuais são subdivididos em duas categorias, a saber: (i) preferenciais, que seriam indivíduos com predisposição ao envolvimento sexual com crianças ou adolescentes, tais como os pedófilos; e (ii) situacionais, que seriam sujeitos que vitimizam crianças e adolescentes muito embora não possuam preferência sexual pelos mesmos.

Prosseguindo, à folha 87, elucida-se que os infratores circunstanciais constituem o grosso dos criminosos carnais, muito embora o grupo não apresente predileção lasciva pela infanto-juventude, tampouco seja motivado por fantasias sexuais com tal segmento. Tais delinquentes se envolvem sexualmente com os imberbes quando e se deparados com situação em que um jovem esteja indefeso ao abuso, assim, geralmente molestando vítimas de fácil acesso.

Por fim, em sua lauda 86, a referida Diretriz expressa preocupação com o uso indevido do termo "pedófilo", asseverando que o vocábulo, bem como a expressão "pedofilia", permanecem incompreendidos, sendo concebidos, vulgarmente, como rótulo apto a qualificar qualquer pessoa condenada por exploração ou abuso sexual de jovens, ignorando-se, portanto, a acepção clínica das locuções.

Tal equívoco conceitual propaga as impostoras ideias de que crimes sexuais contra a mocidade são cometidos exclusivamente por pedófilos e que todos aqueles diagnosticados com a referida parafilia incorrem em tais atos típicos. Nada mais impreciso, diante do revelado no presente capítulo.

À luz de tudo quanto exposto, imperioso que haja uma nítida distinção entre o distúrbio pedófilo e os crimes contra o desenvolvimento

${ }^{60}$ Disponível em: <https://www.interpol.int/News-and-media/News/2016/N2016-080〉. Acesso em: 22 abr. 2018.

${ }^{61}$ Disponível em: <http://luxembourgguidelines.org/english-version/>. Acesso em: 22 abr. 2018. 
sexual de vulnerável, não consistindo esse consectário lógico daquele, tendo em conta que a pedofilia traduz condição clínica que pode ou não resultar em delitos de natureza lasciva. Permita-se repetir, à exaustão: o Direito Penal não opera com base em presunções. 


\section{CAPÍTULO 5 - FORMAS DE COMBATE À VIOLÊNCIA SEXUAL CONTRA VULNERÁVEIS}

Como em todo problema global e multidisciplinar, não existe solução simples para a questão da perversão sexual contra crianças e adolescentes. A matéria demanda atuação conjunta de diversos órgãos públicos, ONGs, bem como o engajamento da sociedade civil.

Um grande passo foi dado pelo Congresso Nacional em 17 de maio de 2000, ocasião em que, por meio da Lei no. 9.970, foi instituído o "Dia Nacional de Combate ao Abuso e à Exploração Sexual de Crianças e Adolescentes", a ser celebrado todo dia 18 do indigitado mês, em homenagem à morte de Araceli Cabrera Crespo, menina de 8 (oito) anos assassinada em Vitória, em 1973, após ter sido sequestrada e violentada.

Embora possa parecer inócua, a medida em espeque reconhece a importância de se promover a conscientização e o debate em relação ao tema, maculado, na origem, pela barreira de silêncio que encobre tópicos incômodos.

Nessa esteira, a mudez deve ser guerreada tanto no âmbito coletivo quanto na esfera doméstica, sendo indispensável que os pais, desde a mais tenra idade, abordem o assunto com seus infantes.

A comunicação familiar é elementar tendo em vista que, dentre os casos de abuso sexual ocorridos em solo nacional, 95\% são praticados por indivíduos do círculo de convivência do imberbe, de modo que é extremamente difícil para a pequena vítima compreender a natureza ilícita do contato, sobretudo diante da circunstância de que nem sempre as experiências são violentas ${ }^{62}$.

Logo, torna-se vital que os genitores, por meio de linguagem acessível, instruam seu rebento quanto ao próprio corpo, alertando que

${ }^{62}$ Disponível em: <https://br.mundopsicologos.com/artigos/vamos-combater-o-abuso-sexual-decriancas-e-adolescentes>. Acesso em: 14 mai. 2018. 
ninguém, sequer pessoas do clã familiar, podem acariciar suas partes íntimas, asseverando, ainda, que na hipótese da ocorrência da relação imprópria, os mesmos devem noticiar o fato. A criança deve compreender o conceito de privacidade e sentir-se dona do próprio corpo.

O combate à taciturnidade também perpassa as redes de ensino, incumbindo às escolas implementar aulas de educação sexual, imprescindíveis ao fomento da percepção dos alunos quanto à violação carnal. Além disso, o corpo docente deve estar preparado para receber eventuais relatos de abuso, tendo em vista que muitas vezes o algoz está inserido no seio familiar, conjectura na qual a escola será a última trincheira de proteção aos vulneráveis.

Nesse diapasão, as instituições de ensino constituem espaços fundamentais na prevenção, identificação e combate ao abuso sexual infantil, valendo ressaltar que o art. 245 do ECA impõe aos professores e responsáveis por entidades de "ensino fundamental, pré-escola ou creche" a obrigação "de comunicar à autoridade competente os casos de que tenha conhecimento, envolvendo suspeita ou confirmação de maus-tratos contra criança ou adolescente".

Além disso, tanto os genitores quanto os educadores devem treinar seus olhares para identificar manifestações não-verbais de violência sexual, tendo em conta que muitas vítimas não vocalizam o abuso, mas sinalizam o trauma por outras formas de expressão.

Nessa esteira, as sequelas decorrentes do defloramento precoce costumam se externar por intermédio de perturbações no sono, mudanças de comportamento repentinas, queda do desempenho escolar, oscilação no apetite e produções gráficas de teor lascivo. A presença de qualquer desses indícios representa motivo de alerta.

O legislativo andou bem, novamente, ao promulgar a Lei $\mathrm{n}^{\mathbf{o}}$. 13.441/2017, que alterou o ECA para incluir a infiltração de agentes 
policiais na internet com o fim de investigar crimes contra a dignidade sexual de crianças e adolescentes.

Frise-se que o meio de investigação em comento dar-se-á mediante requerimento do Ministério Público ou de representação da autoridade policial, ambos fundamentados, sendo necessária a autorização judicial para a sua efetivação, cuja duração não poderá exceder o prazo de 90 (noventa) dias, renováveis até o limite total de 720 (setecentos e vinte) dias.

A infiltração de agentes não é figura nova no ordenamento jurídico, já encontrando guarida na Lei de Drogas (art. 53, I, da Lei no . 11.343/2006) e na Lei de Organização Criminosa (art. 10 da Lei no ${ }^{\circ}$ 12.850/2013), estando, agora, a modalidade de obtenção de prova, prevista, também, para o ambiente virtual/cibernético.

Ressalte-se que a criação de perfil de usuário falso para a coleta de dados em fontes abertas sempre foi possível, já que, para interagir na internet, o usuário aceita abrir mão de grande parte de sua privacidade, logo, sendo possível ao agente investigativo, sem autorização judicial, colher informações públicas e disponibilizadas voluntariamente.

Nessa hipótese, o policial não incidiria na conduta prevista no art. 307 do $\mathrm{CP}$, tendo em vista que o crime de falsa identidade exige elemento subjetivo específico, a saber, a finalidade de obter vantagem ou causar dano a outrem.

Dessa forma, a inovação introduzida pela reforma do Estatuto não está na ocultação da identidade do policial nas redes sociais, o que já podia ser feito licitamente, mas, sim, em viabilizar acesso a informações privadas, em relação às quais há expectativa de privacidade. Ou seja, a novidade reside na possibilidade de penetração do dispositivo informático do investigado para angariar elementos probatórios.

Outra importante inovação na luta contra a criminalidade remonta a 1995, ano em que, no Rio de Janeiro, foi inaugurado o "Disque-Denúncia”, 
inspirado na experiência norte-americana do "Crime Stoppers" e concebido "como uma central comunitária de atendimento telefônico destinada a receber informações anônimas da população"63.

O projeto pioneiro foi um grande sucesso e logo se expandiu para outros Estados brasileiros, tendo, ainda, estimulado a introdução, pelo Governo Federal, do "Disque Direitos Humanos (100)", serviço especializado no recebimento de reclamações envolvendo violações a Direitos Humanos, dentre os quais os crimes contra as crianças e adolescentes.

Nessa esteira, permita-se colacionar, abaixo ${ }^{64}$, gráfico ilustrando as denúncias recebidas, apenas no ano de 2017, pelo canal supracitado, afetas à violação sexual da infanto-juventude, as quais totalizam o montante de 22.324,00 ligações. Veja-se:

\begin{tabular}{|c|c|c|c|c|c|c|c|c|c|c|}
\hline \multicolumn{11}{|c|}{ Disque 100 - Ano 2017 - Violações Violência Sexual de Criança e Adolescente, por UF } \\
\hline UF & $\begin{array}{l}\text { ABUSO } \\
\text { SEXUAL }\end{array}$ & ESTUPRO & $\begin{array}{l}\text { EXPLORAÇÃo } \\
\text { SEXUAL }\end{array}$ & $\begin{array}{c}\text { EXPLORAÇÃO } \\
\text { SEXUAL NO } \\
\text { TURISMO }\end{array}$ & GROOMING & OUTROS & $\begin{array}{l}\text { PORNOGRAFIA } \\
\text { INFANTIL }\end{array}$ & SEXTING & TOTAL & $\%$ \\
\hline AC & 60 & & 14 & & 1 & & 1 & & 76 & $0,34 \%$ \\
\hline AL & 241 & & 62 & & 3 & & 1 & 4 & 311 & $1,39 \%$ \\
\hline AM & 458 & & 160 & 2 & 1 & 3 & 17 & 4 & 645 & $2,89 \%$ \\
\hline AP & 33 & & 14 & & & & & 1 & 48 & $0,22 \%$ \\
\hline BA & 930 & & 250 & 2 & 13 & 1 & 30 & 23 & 1249 & $5,59 \%$ \\
\hline CE & 627 & & 195 & 1 & 18 & 4 & 19 & 15 & 879 & $3,94 \%$ \\
\hline DF & 309 & & 50 & & 7 & & 14 & 3 & 383 & $1,72 \%$ \\
\hline ES & 290 & & 77 & 1 & 5 & 2 & 8 & 7 & 390 & $1,75 \%$ \\
\hline GO & 581 & & 147 & 3 & 8 & 2 & 15 & 6 & 762 & $3,41 \%$ \\
\hline MA & 556 & & 147 & & 8 & 4 & 5 & 5 & 725 & $3,25 \%$ \\
\hline MG & 1572 & & 381 & 1 & 29 & 8 & 55 & 25 & 2071 & $9,28 \%$ \\
\hline MS & 281 & & 86 & 1 & 2 & & 4 & 1 & 375 & $1,68 \%$ \\
\hline MT & 364 & & 87 & 1 & 6 & 3 & 9 & 7 & 477 & $2,14 \%$ \\
\hline PA & 550 & & 149 & & 13 & 7 & 9 & 9 & 737 & $3,30 \%$ \\
\hline PB & 324 & & 113 & & 11 & 2 & 7 & 9 & 466 & $2,09 \%$ \\
\hline PE & 593 & 1 & 165 & 1 & 16 & 1 & 11 & 16 & 804 & $3,60 \%$ \\
\hline PI & 207 & & 58 & 1 & 2 & & & 4 & 272 & $1,22 \%$ \\
\hline PR & 771 & & 165 & 1 & 16 & 4 & 13 & 14 & 984 & $4,41 \%$ \\
\hline $\mathbf{R J}$ & 1293 & & 351 & 3 & 35 & 3 & 34 & 33 & 1752 & $7,85 \%$ \\
\hline RN & 312 & & 88 & & 6 & 2 & 7 & 5 & 420 & $1,88 \%$ \\
\hline RO & 175 & & 44 & & 6 & & 4 & 6 & 235 & $1,05 \%$ \\
\hline RR & 26 & & 9 & & & & 2 & 1 & 38 & $0,17 \%$ \\
\hline RS & 692 & & 191 & 4 & 19 & 4 & 25 & 17 & 952 & $4,26 \%$ \\
\hline SC & 584 & & 176 & & 6 & 1 & 19 & 10 & 796 & $3,57 \%$ \\
\hline SE & 148 & & 53 & & 2 & 1 & 1 & 2 & 207 & $0,93 \%$ \\
\hline SP & 2534 & & 588 & 2 & 50 & 4 & 103 & 51 & 3332 & $14,93 \%$ \\
\hline TO & 84 & & 18 & & & & 1 & 1 & 104 & $0,47 \%$ \\
\hline NA & 52 & & 5 & & 6 & & 2758 & 13 & 2834 & $12,69 \%$ \\
\hline TOTAL & 14647 & 1 & 3843 & 24 & 289 & 56 & 3172 & 292 & 22324 & $100,00 \%$ \\
\hline & $72,05 \%$ & $0,00 \%$ & $18,90 \%$ & $0,12 \%$ & $1,42 \%$ & $0,28 \%$ & $15,60 \%$ & $1,44 \%$ & $109,81 \%$ & \\
\hline
\end{tabular}

63 Disponível em: <http://disquedenuncia.org.br/o-disque-denuncia/A-Origem>. Acesso em: 19 mai. 2018.

${ }^{64}$ Disponível em: <http://www.mdh.gov.br/disque100/balanco-2017-1〉. Acesso em: 19 mai. 2018. 
O passo dado pelo Ministério dos Direitos Humanos no sentido de quantificar e classificar os relatos recebidos é essencial, haja vista que a análise de dados é inerente à compreensão de qualquer problema, de sua dimensão e particularidades, sendo, portanto, as estatísticas, fundamentais para a elaboração de políticas públicas eficazes.

O Brasil não possui base de dados centralizada referente ao tema, havendo um verdadeiro buraco negro informacional e consequente descontrole estatístico por parte das autoridades públicas. Os únicos dados centrais existentes são os do Sistema de Informação de Agravos de Notificação - Sinan, sistema de informações do Ministério da Saúde, que consolida, desde 2011, os atendimentos a diferentes ocorrências médicas, tanto da rede pública quanto da privada.

Entretanto, tais informações se limitam aos casos em que o crime sexual perpetrado acarretou necessidade de intervenção clínica, não abrangendo a universalidade de tais delitos e, ademais, o acompanhamento do sistema de saúde se encerra após o registro, de modo que não se rastreia o desfecho de tais enredos, não se sabendo quantos chegaram à Polícia ou à Justiça.

O que se verifica é uma grave lacuna no país, que sequer sabe o total de relatos de abusos sexuais que chegam às autoridades, tendo em vista que existem diversas fontes aptas a receber as queixas, entretanto, não há a posterior consolidação das informações provenientes dos inúmeros órgãos estatais. Isso decorre da ausência de integração entre os veículos de atendimento, a saber, as Delegacias, o Ministério Público, os Conselhos Tutelares, as Varas da Infância e da Juventude e o próprio DisqueDenúncia.

Além de não se saber o montante de comunicações recebidas, também não se rastreia o desenlace, ou seja, não há registro de quantos dos fatos noticiados chegaram ao Poder Judiciário, quantos resultaram em condenações, etc. 
A despeito do caos estatístico, o IPEA (Instituto de Pesquisas Econômicas Aplicadas) apresentou Nota Técnica, intitulada "Estupro no Brasil: uma radiografia segundo os dados da Saúde", que, com base nos dados reunidos em 2011 pelo Sinan, concluiu que mais de 70\% das vítimas de estupro no país são crianças e adolescentes ${ }^{65}$. Logo, apesar da carência no mapeamento da questão, há indicativos de que a sua dimensão seja alarmante.

A importância da reunião dos dados coletados é reconhecida por outras nações, haja vista que, no Reino Unido, a NSPCC, ONG de prevenção à crueldade contra crianças, agrega os números divulgados pelas diversas entidades governamentais. Já nos EUA, o Departamento de Saúde Federal possui departamento específico de proteção às crianças e adolescentes que emite relatórios periódicos com dados nacionais, trabalho que também é realizado pelo centro de pesquisa "Crimes Against Children Research Center", e o posterior acompanhamento dos relatos é feito pelo FBI.

Nesse diapasão, a inexistência de base de dados uniformizada representa óbice tanto à execução de pesquisas em relação ao tema quanto à formulação de políticas nacionais voltadas à sua resolução, assim, se traduzindo em evidente entrave ao avanço da defesa dos vulneráveis.

Em suma, as demais providências apontadas, tais como a conscientização da população; a educação sexual fornecida no lar e na escola; o treinamento de adultos para identificar sinais de abuso; e a existência de canais aptos a receber denúncias anonimamente; jamais serão suficientes para combater a questão sem que haja investimento em tecnologia que coordene as cifras dos setores do poder público e das entidades da sociedade civil direcionados a batalhar a perversão sexual em face dos mais jovens.

\footnotetext{
${ }^{65}$ Disponível em: 〈http://www.ipea.gov.br/portal/images/stories/PDFs/nota_tecnica/140327_notatecnicadiest11.pdf〉 . Acesso em: 20 mai. 2018.
} 
Por tudo quanto exposto, resta claro que a Doutrina da Proteção Integral, norma de estatura constitucional, reclama, para a sua efetiva consolidação, o desenvolvimento de programa, a nível federal, que articule os informes dos variados organismos operantes, bem como promova o ulterior acompanhamento universal das demandas. A implantação da referida medida geraria estatísticas fidedignas, as quais viabilizariam a real compreensão da mazela configurada pela ofensa à dignidade sexual das crianças e adolescentes, sendo tal diagnóstico intrínseco à criação de políticas específicas de prevenção, atendimento e combate. 


\section{CONCLUSÃO}

Embora múltiplos os fatores que culminam no abuso sexual de vulneráreis, inegável que a questão é agravada por não constituir tema prioritário na agenda pública. Conforme apontado em capítulos antecedentes, durante décadas, o atendimento à infanto-juventude se limitou à prática de encaminhá-la a instituições de internação, realidade que foi alterada a partir da Constituinte de 1987, inspirando, inclusive, a promulgação do ECA poucos anos depois.

Com a edição da novel legislação, o Estado reconheceu que os impúberes ocupariam a qualidade de sujeito de direitos, bem como afirmou seu papel central na proteção integral dos mesmos. A despeito disso, embora tenha avançado no tratamento do menor, o Brasil não promoveu a análoga elaboração de um plano estratégico de longo prazo, coordenado pelo Governo Federal, com envolvimento da sociedade civil, para concretizar os preceitos consubstanciados na Carta Maior e transpostos para a lei de regência.

Nesse diapasão, tampouco foi formulada política pública específica dirigida ao enfrentamento da violência sexual a nível nacional, havendo, apenas, iniciativas esparsas e locais, desintegradas entre si, portanto.

Ao que tudo indica, o país optou por criar amplo aparato jurídico de conteúdo criminal, tendo privilegiado o endurecimento do rigor punitivo, seja pela edição de tipos penais inéditos, seja pelo aumento das penas correspondentes aos delitos de teor lascivo.

Apesar de louváveis as iniciativas citadas, insuficientes, na espécie. O Estado notadamente adotou um viés ofensivo eminentemente criminal, preferindo acoimar e repreender o sujeito ativo em vez de investir na polaridade passiva, a saber, as crianças e adolescentes. $\mathrm{O}$ país providenciou a edição de compreensiva legislação proibitiva, entretanto, olvidou-se, no 
azo, de desenvolver um sistema de proteção social, que perpassaria diversos ramos, tal como a saúde, a educação, a cultura e a justiça.

Houve devoção, repita-se, à criminalização de potenciais condutas libidinosas delitivas, ignorando-se, por completo, a total incapacidade do Direito Penal em servir como instrumento de melhoria social, o que se extrai da inescapável cifra negra que circunda todas as condutas criminosas, já evidenciada no século passado pelo sociólogo Edwin Sutherland.

Nesse ponto, destaque-se que o IPEA produziu estudo apontando que a cifra oculta atinge o índice de $90 \%$ nos casos de estupro, de modo que apenas $10 \%$ de tais delitos chegam ao conhecimento das autoridades ${ }^{66}$.

A subnotificação ilustrada demonstra, irrefutavelmente, que a legislação criminal não pode constituir o principal veículo de combate à violação carnal da infância e juventude, devendo representar, somente, instrumento subsidiário, a ser aplicado como ultima ratio, quando os métodos preventivos houverem falhado.

Sobretudo diante das informações, trazidas no Capítulo 4, que revelam que cerca de $80 \%$ dos abusadores sexuais de jovens são "infratores situacionais", ou seja, indivíduos que agem motivados pela indefensibilidade e acessibilidade da vítima, e não por possuir disfunção pedófila, salta aos olhos que a única saída possível é combater a negligência para com as crianças e adolescentes.

Em suma, além da urgente implementação de políticas públicas nacionais, a serem traçadas com arrimo em estudos estatísticos advindos de dados integrados dos órgãos atuantes na seara, imprescindível a adoção de medidas que obstem à exposição de vulneráveis a potenciais oportunidades delitivas, seja possibilitando educação em período integral, seja criando ambientes de lazer coletivo, seja assegurando o acesso à cultura ou garantindo o convívio familiar e comunitário. Conclui-se, por tudo e por

\footnotetext{
${ }^{66}$ Disponível em:

<http://www.ipea.gov.br/portal/index.php?option=com_content\&view=article\&id=21848>.

Acesso em: 21 de maio de 2018.
} 
tanto quanto exposto, que a Doutrina da Proteção Integral remanesce o baluarte da salvaguarda à infância e juventude, configurando a mais completa diretriz de preservação concebida, até então, pelo homem. 


\section{REFERÊNCIAS BIBLIOGRÁFICAS}

ALEXY, Robert. Teoria de los Derechos Fundamentales. Madri: Centro de Estúdios Políticos y Constitucionales, 2001.

ARÍES, Philippe; DUBY, Georges. História da Vida Privada - Da Renascença ao Século das Luzes. Hildegard Fiest (Trad.). São Paulo: Companhia das Letras, 1991.

ARRUDA, Kátia Magalhães. O Trabalho de Crianças no Brasil e o Direito Fundamental à Infância. In: Dos Direitos Humanos aos Direitos Fundamentais. 1997.

BARROSO, Luís Roberto. Interpretação e aplicação da Constituição: fundamentos de uma dogmática constitucional transformadora. $6^{\circ}$ ed., São Paulo: Saraiva, 2008.

O Direito Constitucional e Eficácia das Normas. $9^{a}$ ed., Rio de Janeiro: Ed. Renovar, 2009.

BATISTA, Dayse. Dsm-IV: manual de diagnostico e estatístico de transtornos mentais. $4^{\mathrm{a}}$ ed., Porto Alegre: Artes Médicas, 1995.

BITENCOURT, Luciane Potter. Vitimização secundária infanto-juvenil e violência sexual intrafamiliar. Rio de Janeiro: Lumen Juris, 2009.

BITTENCOURT, Cezar Roberto. Tratado de Direito Penal. v. 1, 22a ed., São Paulo: Saraiva, 2016.

. Tratado de Direito Penal. v. 4, $11^{\text {a }}$ ed., São Paulo: Saraiva, 2017.

BRASIL. Constituição (1988). Constituição da República Federativa do Brasil. Brasília, DF, Senado, 1998.

BRASIL. Lei n ${ }^{\circ}$ 6.697, de 10 de outubro de 1979. Institui o Código de Menores. Disponível em: <http://www2.camara.leg.br/legin/fed/lei/19701979/lei-6697-10-outubro-1979-365840-publicacaooriginal-1-pl.html>.

Acesso em: 22 abr. 2018.

BRASIL. Lei $\mathrm{n}^{\circ}$ 8.069, de 13 de julho de 1990. Dispõe sobre o Estatuto da Criança e do Adolescente e dá outras providências. Disponível em: 
<http://www.planalto.gov.br/ccivil_03/leis/18069.htm>. Acesso em: 22 abr. 2018.

BRASIL. Lei n ${ }^{\circ}$ 10.406, de 10 de janeiro de 2002. Código Civil. Disponível em: <http://www.planalto.gov.br/ccivil_03/leis/2002/L10406.htm>. Acesso em: 20 mar. 2017.

BRASIL. Congresso Nacional. Câmara dos Deputados. Exposição de Motivos da Câmara dos Deputados em relação à Lei 12.015/2009, 2004. Disponível em: <http://www2.camara.leg.br/legin/fed/lei/2009/lei12015-7-agosto-2009-590268-exposicaodemotivos-149280-pl.html> . Acesso em: 30 mar. 2018.

BRASIL. Decreto-Lei no 2.848, de 7 de dezembro de 1940. Código Penal. Disponível em: <http://www.planalto.gov.br/ccivil_03/decretolei/Del2848compilado.htm>. Acesso em: 22 abr. 2018.

BRASIL. Decreto-Lei $\mathrm{n}^{\circ}$ 3.688, de 3 de outubro de 1941. Lei das Contravenções Penais. Disponível em:

<http://www.planalto.gov.br/ccivil_03/decreto-lei/Del3688.htm>. Acesso em: 22 abr. 2018.

CAPEZ, Fernando. Direito Penal Simplificado: Parte Geral. 15ª ed., São Paulo: Saraiva, 2012.

CARVAlHO, Olavo de. Cem Anos de Pedofilia. Disponível em: <http://www.olavodecarvalho.org/cem-anos-de-pedofilia/>. Acesso em: 22 abr. 2018.

CONDE, Francisco Muñoz. Direito Penal - Parte Especial. 12a ed., Valência: Tirant lo Blanch, 1999.

CUNHA, Rogério Sanches. Comentários à reforma criminal de 2009. São Paulo: Revista dos Tribunais, 2009.

Direito Penal, Parte Especial. $3^{\mathrm{a}}$ ed., São Paulo: Revista dos Tribunais, 2010.

Disponível em: <http://luxembourgguidelines.org/english-version/>. Acesso em: 22 abr. 2018.

Disponível em: <http://www.un-documents.net/gdrc1924.htm>. Acesso em: 05 mai 2018. 
Disponível em: <https://br.mundopsicologos.com/artigos/vamos-combatero-abuso-sexual-de-criancas-e-adolescentes>. Acesso em: 14 mai. 2018.

Disponível em: <https://www.interpol.int/News-andmedia/News/2016/N2016-080>. Acesso em: 22 abr. 2018.

Disponível em:

<http://bvsms.saude.gov.br/bvs/publicacoes/prevencao_agravo_violencia_s exual_mulheres_3ed.pdf>. Acesso em: 05 mai. 2018.

Disponível em: <http://disquedenuncia.org.br/o-disque-denuncia/AOrigem>. Acesso em: 19 mai. 2018.

Disponível em:

<http://journals.sagepub.com/doi/abs/10.1177/107906320101300103>. Acesso em: 22 abr. 2018.

Disponível em: <http://www.europsy-journal.com/article/S09249338\%2814\%2977731-4/abstract>. Acesso em: 22 abr. 2018.

Disponível em:

<http://www.ipea.gov.br/portal/images/stories/PDFs/nota_tecnica/140327_ notatecnicadiest11.pdf >. Acesso em: 20 mai. 2018.

Disponível em: <http://www.mdh.gov.br/disque100/balanco-2017-1> . Acesso em: 19 mai. 2018.

Disponível em: <http://www.vatican.va/archive/cod-iuriscanonici/portuguese/codex-iuris-canonici_po.pdf $>$. Acesso em: 22 abr. 2018.

Disponível em:

<http://www2.stf.jus.br/portalStfInternacional/cms/verConteudo.php?sigla= portalStfJurisprudencia_pt_br\&idConteudo $=185145 \& \operatorname{modo}=\mathrm{cms}>$. Acesso em: 20 mai. 2018.

Disponível em: <https://www.dutchrapporteur.nl/binaries/dutchrapporteur.on-solid-ground.tackling-sexual-violence-againstchildren.2014_tcm24-35335.pdf>. Acesso em: 22 abr. 2018.

FERRARI, Regina Maria Macedo Nery. Normas Constitucionais Programáticas - Normatividade, Operatividade. 1a ed., São Paulo: Ed. Revista dos Tribunais, 2001. 
GOFF, Jacques Le. O Nascimento do Purgatório. AZEVEDO, Maria Fernanda Gonçalves de (Trad.). São Paulo: Estampa, 1981.

GRECO, Rogério. Código Penal Comentado. $4^{\mathrm{a}}$ ed., Niterói: Impetus, 2010.

HUNGRIA, Nelson. Comentários ao Código Penal. 5a ed., v. VIII. Rio de Janeiro: Forense, 1981.

HUNGRIA, Nelson. Comentários ao Código Penal. cit., v. 1, t. 2. Rio de Janeiro: Forense, 1949.

JASMIM, Marcelo Gantus. Para uma História da Legislação sobre o Menor. In: Revista de Psicologia, ${ }^{\circ}$ 4, 1986.

KELSEN, Hans. Teoria Pura do Direito. São Paulo: Martins Fontes, 1987.

LAIOU, Abgeliki. Coercion to sex and marriage in ancient and medieval societies. Washington, DC: Harvard University Press, 1998.

LOPES JUNIOR, Aury. Introdução Crítica ao Processo Penal. $4^{\mathrm{a}}$ ed., Rio de Janeiro: Lumen Juris Editora, 2006.

MAXIMILIANO, Carlos. Hermenêutica e Aplicação do Direito. $8^{\mathrm{a}}$ ed., São Paulo: Freitas Bastos, 1965.

NUCCI, Guilherme de Souza. Crimes contra a dignidade sexual Comentários da Lei 12.015. São Paulo: Revista dos Tribunais, 2009.

. Estatuto da Criança e do Adolescente Comentado: em busca da Constituição Federal das Crianças e dos Adolescentes. $3^{\text {a }}$ ed., Rio de Janeiro: Forense, 2017.

PLATÃO. O Banquete, ou, Do amor. SOUZA, José Cavalcante de. (Trad.). Rio de Janeiro: DIFEL, 2008.

RANGEL, Paulo. Direito Processual Penal. $17^{\mathrm{a}}$ ed., Rio de Janeiro: Lumen Juris, 2009.

ROXIN, Claus. Derecho Penal: parte general. t.1, Madrid: Civitas, 1997.

SAITO, Osamu. Historical demography: achievements and prospects. v. 50, n. 3. Population Studies, 1996. 
STF, Habeas Corpus $n^{\circ}$. 73.662/MG, SEGUNDA TURMA, Rel. Ministro Marco Aurélio de Mello, Data de julgamento: 21/05/1996, Data de Publicação: DJ 20/09/1996.

STJ, Habeas Corpus n. 276.510/RJ, Rel. Ministro Sebastião Reis Júnior, Sexta Turma, Data de julgamento: 11/11/2014, DJe: 01/12/2014.

STJ, Habeas Corpus n. 155.149/RJ, Rel. Ministro Félix Fischer, publicado em 11/06/2010. p. 193-194.

STJ, Recurso Especial no. 884333/SC, QUINTA TURMA, Relator: Ministro GILSON DIPP, Data de Julgamento: 10/05/2007, Data de Publicação: DJ 29/06/200, p. 708.

STJ, Recurso Especial (repetitivo), no. 1.480.881/PI, Terceira Seção, Rel. Ministro Rogério Schietti, julgamento em: 27/08/2015, Data de Publicação: DJe 10/09/2015.

STJ, Recurso Especial 1.543.267/SC, SEXTA TURMA, Rel. Ministra Maria Thereza de Assis Moura, Data de julgamento: 03/12/2015, DJe $16 / 02 / 2016$

TOLEDO, Francisco de Assis. Princípios Básicos de Direito Penal. $5^{\mathrm{a}}$ ed., São Paulo: Saraiva, 1994. 